\title{
Discriminative stimulus properties of atypical and typical antipsychotic drugs: a review of preclinical studies
}

\author{
Joseph H. Porter • Adam J. Prus
}

Received: 10 June 2008 / Accepted: 19 August 2008 / Published online: 16 September 2008

(C) Springer-Verlag 2008

\begin{abstract}
Background Drug discrimination is an increasingly valuable behavioral assay for the preclinical development of antipsychotic drugs. The majority of studies have used the atypical antipsychotic clozapine because it displays robust discriminative stimulus properties and is the "prototypical" or "gold standard" atypical antipsychotic against which other antipsychotics will undoubtedly be compared for many years.

Objectives Pharmacological mechanisms mediating the discriminative stimulus properties of antipsychotics used as training drugs and the usefulness of drug discrimination for distinguishing typical and atypical antipsychotics were reviewed.

Results Clozapine appears to have a compound cue involving antagonism of two or more receptors. While muscarinic receptor antagonism is a prominent factor for mediation of clozapine's cue in rats with a $5.0-\mathrm{mg} / \mathrm{kg}$ training dose, there are differences in clozapine's cue with a low training dose and in pigeons and mice. With a low training dose, clozapine has consistently produced full or partial generalization to atypical but not to typical antipsychotics. Although not evaluated as extensively, the atypical antipsychotics quetiapine and ziprasidone also appear to generalize to atypical but not typical antipsychotics. This has not been the case for other antipsychotic
\end{abstract}

J. H. Porter $(\bowtie)$

Department of Psychology, Virginia Commonwealth University, 806 West Franklin Street, P.O. Box 842018, Richmond, VA, USA e-mail: jporter@vcu.edu

A. J. Prus

Department of Psychology, Northern Michigan University, Marquette, MI, USA drugs (olanzapine, chlorpromazine, haloperidol) used as training drugs.

Conclusions There are important differences in discriminative stimulus properties both between and within atypical and typical antipsychotics and across species. While lowdose clozapine discrimination in rats appears to provide a more sensitive behavioral assay for distinguishing atypical from typical antipsychotics, the extent to which clozapine's discriminative stimulus properties are predictive of its antipsychotic effects remains to be determined.

Keywords Antipsychotic drugs · Clozapine ·

Drug discrimination - Discriminative stimulus properties .

Training dose $\cdot$ Schizophrenia $\cdot$ Rats $\cdot$ Mice $\cdot$ Pigeons .

Monkeys

\section{Introduction}

The introduction of the antipsychotic drugs chlorpromazine and haloperidol in the $1950 \mathrm{~s}$ radically changed the treatment and prognosis of schizophrenia. These and similar acting drugs, now classified as "typical" or "classical" antipsychotic drugs, are relatively effective in relieving the positive symptoms of schizophrenia (e.g., hallucinations, delusions, excited motor behaviors, thought disorders), but offer little efficacy for the negative symptoms (e.g., emotional and social withdrawal, flat affect, slowness, impoverishment of thought and speech; see Crow 1987) or cognitive deficits in schizophrenia (Meltzer and McGurk 1999; Woodward et al. 2005). In addition, typical antipsychotic drugs produce extrapyramidal motor side effects at therapeutic doses and long-term treatment may result in tardive dyskinesia (see review by Ellenbroek 1993). 
The first antipsychotic drug found to differ substantially in therapeutic efficacy and side effect liability was clozapine. Clozapine is referred to as an atypical or novel antipsychotic drug because it produces few, if any, extrapyramidal motor effects and is usually tolerated better than typical antipsychotic drugs (Claghorn et al. 1987; Kane et al. 1988; Meltzer 1992; Ellenbroek 1993; Arnt and Skarsfeldt 1998). Chronic treatment with clozapine does not appear to cause tardive dyskinesia (Casey 1989) or prolonged elevations in serum prolactin levels (Meltzer 1992). Most of the therapeutic effects of clozapine are shared by antipsychotic drugs placed on the market since the 1980s, which are also referred to as "atypical," including olanzapine, risperidone, sertindole, quetiapine, and ziprasidone. All of these compounds share in common a preferential affinity, as antagonists or inverse agonists, for the serotonin $(5-\mathrm{HT})_{2 \mathrm{~A}}$ receptor over the dopamine $\mathrm{D}_{2}$ receptor (Meltzer et al. 1989; Schotte et al. 1996). Aripiprazole, another compound that exhibits atypical antipsychotic-like properties clinically, differs slightly from this receptor profile by acting as a weak $\mathrm{D}_{2}$ receptor partial agonist, although it has a high affinity as an antagonist for the 5- $\mathrm{HT}_{2 \mathrm{~A}}$ receptor (Shapiro et al. 2003). Amisulpride also has a clinical profile of an atypical antipsychotic drug but lacks $5-\mathrm{HT}_{2 \mathrm{~A}}$ antagonism. Instead, it displays a preferential blockade of presynaptic $\mathrm{D}_{2} / \mathrm{D}_{3}$ receptors in mesolimbic dopamine pathways (Möller 2003). More recently, interest has turned to the active metabolites of atypical antipsychotic drugs in the hope that they might have increased efficacy over the parent drug and a reduced incidence of side effects. The active metabolite of risperidone, 9-OH-risperidone (paliperidone [Invega $\left.{ }^{\circledR}\right]$ ) from Janssen Pharmaceuticals, has recently met FDA approval and is being used clinically for the treatment of schizophrenia in the US (Dlugosz and Nasrallah 2007; Dolder et al. 2008). The active metabolite for clozapine, $N$-desmethylclozapine ( $\mathrm{Li}$ et al. 2005), was being developed by Acadia Pharmaceuticals, as ACP-104, for the treatment of schizophrenia; however, a recent press release (Reuters, June 16 2008) reported that ACP-104 did not display antipsychotic efficacy compared to placebo in Phase IIb clinical trials. Clozapine still remains unique in therapeutic efficacy compared to other available atypical antipsychotic drugs in many ways, including an ability to reduce the severity of preexisting tardive dyskinesia symptoms (Meltzer and Luchins 1984; Lieberman et al. 1989) and an increased efficacy in the majority of patients who are resistant to treatment with other antipsychotic drugs (Honigfeld et al. 1984; Kane et al. 1988; Young et al. 1997). However, it should be noted that the recent series of Clinical Antipsychotic Trials of Intervention Effectiveness (CATIE) studies have raised some doubts about the superiority of atypical antipsychotic drugs, in general, over typical antipsychotic drugs such as haloperidol and chlorpromazine (see Meyer 2007; Lewis and Lieberman 2008).
While a large number of different preclinical behavioral tests have been used for screening drugs in the development of new atypical antipsychotics (see Ellenbroek 1993; Arnt and Skarsfeldt 1998; Geyer and Ellenbroek 2003 for reviews), the focus of the present review is on drug discrimination. In particular, this review will focus on studies in which antipsychotic drugs have been used as the training drug. For reviews of drug discrimination studies in which antipsychotic drugs have been tested for their ability to block the discriminative stimulus properties of other training drugs (like low-dose amphetamine discrimination, DOI discrimination, and MK-801 discrimination) see Arnt and Skarsfeldt (1998) and Goudie and Smith (1999). In addition, the present review did not attempt to review the discriminative stimulus properties of putative antipsychotic drugs such as MDL 100,907 (Dekeyne et al. 2003) or S 16924 (Millan et al. 1998, 1999).

Drug discrimination procedures have been widely used as behavioral assays in the preclinical development and testing of drugs for a number of years (e.g., Meert 1991; Arnt and Skarsfeldt 1998; Millan et al. 2000; Goudie et al. 2006), and the drug discrimination paradigm can be used both to classify drugs and to identify underlying pharmacological mechanisms that mediate the discriminative stimulus properties of the drugs being studied (e.g., Winter and Rabin 1989; Kelley and Porter 1997; Goudie et al. 1998c; Colpaert 1999; Philibin et al. 2005; Goudie et al. 2006). As in all behavioral assays, procedural variables can be an important factor in determining the results obtained. In the drug discrimination assay, the procedures that vary the most are the route of injection (this information will be provided as studies are introduced), the time of the injection (typically 30 to $60 \mathrm{~min}$ in most studies), the reinforcement schedule (fixed ratio 30 or 10 reinforcement schedules in most studies), and the reinforcer (typically food-either pellets or a liquid, such as water or sweetened milk). In spite of these differences across studies, the results tend to be very consistent for the training drugs and the test drugs. The major differences that have been found in these studies are more often related to the species and to the dose of the training drug, and both of these variables will be discussed.

The present review will first present a historical overview of the early studies that first attempted to study the discriminative stimulus properties of typical and atypical antipsychotics (sometimes with less than stellar results). Then, the discriminative stimulus properties of the atypical antipsychotics clozapine and other atypical antipsychotic drugs and the typical antipsychotics chlorpromazine and haloperidol will be discussed in detail. As will be obvious, the vast majority of this research has focused on clozapine which remains the "prototypical" or "gold standard" antipsychotic drug against which all other current and future antipsychotics will, undoubtedly, be compared for 
many years. An overview of the pharmacological mechanisms that mediate the discriminative stimulus properties of these antipsychotics will be presented, and finally, the usefulness of the drug discrimination assay for distinguishing among typical and atypical antipsychotics, and the extent to which the discriminative stimulus properties of antipsychotic drugs reflect or are predictive of their therapeutic effects for treating schizophrenia, will be discussed.

\section{Overview of early discrimination studies with antipsychotic drugs}

The first successful report that animals could discriminate an antipsychotic drug was by Stewart (1962). Rats were trained to discriminate $4.0 \mathrm{mg} / \mathrm{kg}$ (i.p.) chlorpromazine from saline in a shock-avoidance task using a three-compartment test chamber (a procedure somewhat analogous to a T-maze). There was a dose-dependent generalization curve for chlorpromazine with drug appropriate responding ranging from $28.9 \%(2.0 \mathrm{mg} / \mathrm{kg}$ chlorpromazine $)$ to a maximum of $94.3 \%$ at the $4.0 \mathrm{mg} / \mathrm{kg}$ training dose. Substitution testing revealed that the phenothiazines acepromazine, perphenazine, and prothipendyl fully substituted for chlorpromazine, but that the phenothiazine prochlorperazine, and the tricyclic antidepressant imipramine did not. Overton (1966) attempted to establish discrimination with a $5.0-\mathrm{mg} / \mathrm{kg}$ (i.p.) dose of chlorpromazine in a T-maze (shock avoidance), but reported that no discrimination could be established. Harris and Balster (1971) also reported that discriminative control with chlorpromazine $(1.0 \mathrm{mg} / \mathrm{kg}$, i.p.) could not be established in a two-lever operant conditioning procedure, although it should be noted that only two rats were tested.

Barry et al. (1974) were the first to establish drug discrimination with chlorpromazine $(1.0 \mathrm{mg} / \mathrm{kg}$ training dose versus saline, i.p.) in a two-lever operant task (food reinforcement on one lever; shock punishment on the other lever). Several chlorpromazine metabolites were tested, and only one (7-OH-CPZ) was able to produce chlorpromazine-appropriate responding. Interestingly, quaternary chlorpromazine failed to substitute for chlorpromazine indicating that the discriminative stimulus properties of chlorpromazine were mediated centrally, not peripherally. Haloperidol was first established as the training drug in a two-lever operant discrimination (food reward) by Colpaert et al. (1976). Rats were trained to discriminate $0.02 \mathrm{mg} / \mathrm{kg}$ (s.c.) haloperidol from saline, although the authors reported that it was difficult to establish the discrimination with over 80 training sessions being required (compared to only 35 sessions for chlordiazepoxide and 40 sessions for amphetamine). Unfortunately, no other drugs were tested in that study.

Goas and Boston (1978) provided the first demonstration that the atypical antipsychotic clozapine $(6.9 \mathrm{mg} / \mathrm{kg}$, p.o.) could be established as a training drug (versus vehicle) in a two-lever operant discrimination task (food reinforcement). In a separate group of rats, they also established a discrimination between $2.0 \mathrm{mg} / \mathrm{kg}$ chlorpromazine (p.o.) and vehicle. Substitution testing demonstrated that both haloperidol, clozapine, and the muscarinic antagonist benztropine mesylate produced full substitution for chlorpromazine; whereas, chlordiazepoxide did not. In the clozapine-trained rats, none of the tested drugs substituted for clozapine; these included chlorpromazine, haloperidol, chlordiazepoxide, and atropine. Thus, the generalization between clozapine and chlorpromazine was not symmetrical. Goas and Boston also established a drug-drug discrimination with $8.8 \mathrm{mg} / \mathrm{kg}$ clozapine versus $4.24 \mathrm{mg} / \mathrm{kg}$ chlorpromazine (p.o.) and found that haloperidol substituted for chlorpromazine. Using a Tmaze discrimination procedure, Overton (1982) reported that clozapine $(20 \mathrm{mg} / \mathrm{kg}$, i.p.) and haloperidol $(2.5 \mathrm{mg} / \mathrm{kg}$, i.p.) could be established as training drugs; whereas, no drug discrimination could be established with the antipsychotic drugs chlorpromazine, fluphenazine, haloperidol, or thioridazine. No substitution tests were conducted in this study.

\section{Discriminative stimulus properties of clozapine}

Clozapine, a dibenzodiazepine, differs from typical neuroleptics such as haloperidol, a butyrophenone, and chlorpromazine, a phenothiazine, in that it binds with a relatively low affinity to dopamine $\mathrm{D}_{2}$ receptors but has a higher affinity for $\mathrm{D}_{1}$ receptors. Clozapine displays a high binding affinity for a number of other neurotransmitter receptors including dopaminergic $\mathrm{D}_{4}$, serotonergic $5-\mathrm{HT}_{2 \mathrm{~A} / 2 \mathrm{C}}, 5-\mathrm{HT}_{6}$, 5-HT $\mathrm{H}_{7}$, cholinergic $\mathrm{M}_{1}, \mathrm{M}_{2}, \mathrm{M}_{3}, \mathrm{M}_{4}$, adrenergic $\alpha_{1}, \alpha_{2}$, and histaminergic $\mathrm{H}_{1}$ receptors (Bymaster et al. 1996; Schotte et al. 1996; Arnt and Skarsfeldt 1998; Richelson 1999). While generally characterized as an antagonist at these receptors, clozapine has been shown to display weak partial agonist activity at $\mathrm{M}_{1}$ receptors (Davies et al. 2004; Weiner et al. 2004) and agonist activity at $\mathrm{M}_{4}$ and $5-\mathrm{HT}_{1 \mathrm{~A}}$ receptors (Zeng et al. 1997; Arnt and Skarsfeldt 1998; Newman-Tancredi et al. 2005). These agonist properties of clozapine may contribute to the therapeutic efficacy of clozapine. For example, it has been suggested that agonist activity at 5$\mathrm{HT}_{1 \mathrm{~A}}$ receptors may play a role in the treatment of negative and cognitive symptoms, enhancing mood, and reducing extrapyramidal motor side effects (Millan 2000). Because of this very diverse binding profile, the underlying pharmacological mechanisms of clozapine's discriminative stimulus properties have not been fully resolved. As discussed below, the two neurotransmitter receptors that seem to be the most promising candidate's for mediation of clozapine's cue are muscarinic cholinergic receptors and $5-\mathrm{HT}_{2 \mathrm{~A} / 2 \mathrm{C}}$ serotonergic receptors, although there may be differences across species 
Table 1 Antagonism of clozapine's discriminative cue (rats trained to discriminate $5.0 \mathrm{mg} / \mathrm{kg}$, i.p. clozapine from vehicle) by the muscarinic cholinergic xagonist oxotremorine $(N=8)$

\begin{tabular}{lccccc}
\hline & $\begin{array}{l}\text { Vehicle } \\
\text { control }\end{array}$ & $\begin{array}{l}5.0 \mathrm{mg} / \mathrm{kg} \\
\text { clozapine control }\end{array}$ & $\begin{array}{l}\text { Clozapine }+ \\
0.0325 \mathrm{mg} / \mathrm{kg} \mathrm{OXO}\end{array}$ & $\begin{array}{l}\text { Clozapine }+ \\
0.0625 \mathrm{mg} / \mathrm{kg} \mathrm{OXO}\end{array}$ & $\begin{array}{l}\text { Clozapine }+ \\
0.125 \mathrm{mg} / \mathrm{kg} \mathrm{OXO}\end{array}$ \\
\hline Percent drug lever responding & $\begin{array}{c}0.25 \%(0.2) \\
\text { Mean responses per minute }\end{array}$ & $\begin{array}{c}96.1 \%(2.3) \\
89.1(10.2)\end{array}$ & $\begin{array}{c}82.4 \%(13.4) \\
49.6 * *(9.6)\end{array}$ & $\begin{array}{c}79.1 \%(17.1) \\
20.1 * *(11.2)\end{array}$ & $\begin{array}{r}61.7 \% * *(17.6) \\
24.4 * *(8.5)\end{array}$ \\
\hline
\end{tabular}

The peripheral antagonist methylscopolamine $(1.5 \mathrm{mg} / \mathrm{kg})$ was co-administered with the Vehicle and Clozapine Control Tests and with drug combination tests to block the peripheral effects of oxotremorine. (Data from Kelley et al. 1994)

**Significantly different from Clozapine Control, $p<0.01$

(i.e., rats versus mice versus pigeons), and training dose may play an important role. Another possibility is that the basis of clozapine's discriminative stimulus properties may be a compound cue involving antagonism of two or more receptors simultaneously. These possibilities will be discussed more fully below.

\section{Cholinergic antagonism}

Nielsen (1988) argued that muscarinic cholinergic antagonism mediates clozapine's discriminative stimulus properties, as evidenced by the ability of scopolamine (see also Franklin and Tang 1994), atropine, and fluperlapine to substitute for clozapine in rats trained to discriminate $5.76 \mathrm{mg} / \mathrm{kg}$ (i.p.) clozapine from vehicle. Nielson reported that the muscarinic agonist oxotremorine blocked the clozapine cue (a 1.0-mg/kg dose decreased clozapineappropriate responding to $22 \%$ ), although no statistical analysis was performed due to an insufficient number of animals responding. Kelley et al. (1994) also have shown that the clozapine cue can be attenuated by the muscarinic agonist oxotremorine (see Table 1). While a significant reduction in response rates was seen at the oxotremorine dose $(0.125 \mathrm{mg} / \mathrm{kg}$, i.p.) that significantly reduced clozapine-appropriate responding, response rates also were significantly reduced by two lower doses where there were no significant changes in clozapine-appropriate responding. Methylscopolamine (1.5 mg/kg, i.p.) was co-administered to block the peripheral effects of oxotremorine in this study, and it had no effect on the Vehicle and Clozapine Control Tests.

Findings by Kelley and Porter (1997) also support the importance of muscarinic antagonism in the discriminative stimulus properties of clozapine in rats. First, they found complete cross-generalization between $5.0 \mathrm{mg} / \mathrm{kg}$ (i.p.) clozapine-trained rats and $0.125 \mathrm{mg} / \mathrm{kg}$ (i.p.) scopolaminetrained rats - a finding indicative of a shared common mechanism for the discriminative stimulus properties of the two drugs (see Schuster and Balster 1977). Second, the $\mathrm{M}_{1}$ muscarinic antagonist trihexyphenidyl substituted completely for both clozapine and scopolamine, but the $\mathrm{M}_{2}$ muscarinic antagonist BIBN 99 did not substitute for either clozapine or scopolamine, suggesting that antagonism of the $\mathrm{M}_{1}$ muscarinic receptor plays an important role in the mediation of clozapine's discriminative cue. Results for the drugs tested in that study are summarized in Fig. 1, showing the highest percent drug-lever responding for scopolamine ( $Y$ axis) as a function of the highest percent responding for clozapine ( $X$ axis). As can be seen in Fig. 1, there was a strong positive correlation $(r=0.74, p<0.01)$ between the highest percent scopolamine-responding and the highest percent clozapine-responding for these drugs. In general, Kelley and Porter (1997) found that drugs with higher binding affinities at muscarinic receptors substituted at higher percentages for clozapine and scopolamine, with two notable exceptions. The benzodiazepine chlordiazepoxide has no affinity for muscarinic receptors, yet showed partial substitution for both clozapine and scopolamine. This partial substitution may reflect an indirect interaction with cholinergic systems, as it has been shown that the

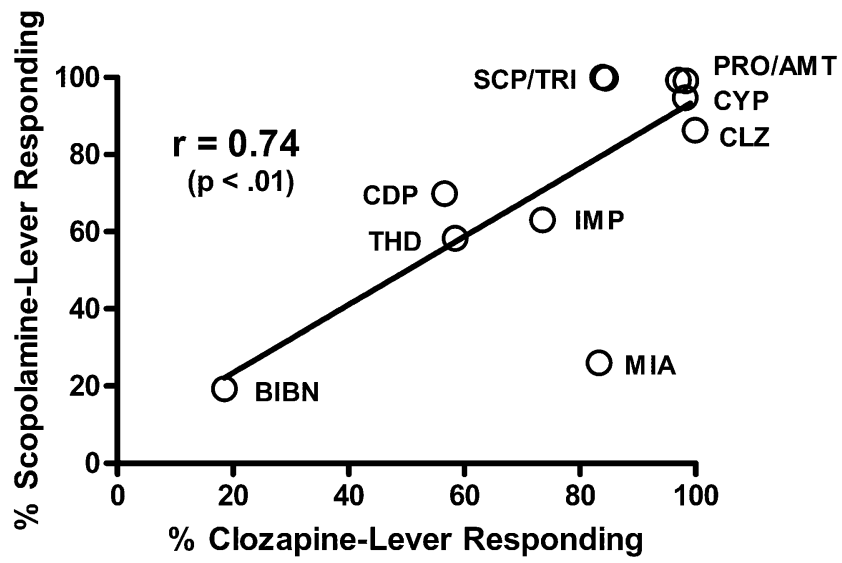

Fig. 1 Results are summarized for drugs tested both in rats trained to discriminate $5.0 \mathrm{mg} / \mathrm{kg}$ (i.p.) clozapine from vehicle and in rats trained to discriminate $0.125 \mathrm{mg} / \mathrm{kg}$ (i.p.) scopolamine from vehicle in a twolever operant task (adapted from Kelley and Porter 1997). The highest percent of scopolamine-lever responding ( $Y$ axis) is shown as a function of the highest percent of clozapine-lever responding ( $X$ axis) for each drug. The regression line for the data and the correlation coefficient are also shown. Amitriptyline (AMT); BIBN-99 (BIBN); Chlordiazepoxide (CDP; Clozapine (CLOZAPINE); Cyproheptadine (CYP); Imipramine (IMP); Mianserin (MIA); Promethazine (PMZ); Scopolamine (SCP); Thioridazine (THD); Trihexyphenidyl (TRI) 
benzodiazepine agonist diazepam decreases acetylcholine levels in the hippocampus (Imperato et al. 1994). The other exception was the tetracyclic antidepressant, mianserin. Mianserin was the only drug tested in the Kelley and Porter (1997) study that substituted for clozapine, but failed to substitute for scopolamine. All of the drugs that produced full substitution for clozapine in that study display low nanomolar affinity for muscarinic receptors, except for mianserin which has a KD of $469.0 \mathrm{nM}$ (Golds et al. 1980). Interestingly, Prus et al. (2006) found that in rats trained to discriminate $1.25 \mathrm{mg} / \mathrm{kg}$ clozapine from $5.0 \mathrm{mg} / \mathrm{kg}$ clozapine from vehicle (i.p.) in a three-lever drug discrimination task, mianserin was the only drug among several selective ligands that produced full substitution for clozapine (on the $5.0 \mathrm{mg} / \mathrm{kg}$ training-dose lever). In rats trained to discriminate $4.0 \mathrm{mg} / \mathrm{kg}$ (i.p.) mianserin from vehicle, scopolamine substituted for mianserin ( $88 \%$ maximum generalization at $1.0 \mathrm{mg} / \mathrm{kg}$ scopolamine); however, mianserin did not substitute for scopolamine in rats trained to discriminate $0.25 \mathrm{mg} / \mathrm{kg}$ (i.p.) scopolamine from vehicle (Kelley et al. 1995). Thus, the basis for the generalization of clozapine's discriminative cue to mianserin remains to be determined.

The role for muscarinic receptor antagonism in the discriminative stimulus properties of clozapine in rats also has been supported by other studies. In a study by Goudie et al. (1998c), in which a large number of selective receptor antagonists were tested in rats trained to discriminate $5.0 \mathrm{mg} / \mathrm{kg}$ (i.p.) clozapine from vehicle, they found that only the muscarinic receptor antagonist scopolamine produced full substitution for the clozapine cue. Millan et al. (1999) also reported that scopolamine fully substituted for $5.0 \mathrm{mg} / \mathrm{kg}$ (i.p.) clozapine. Prus et al. (2004) reported that the muscarinic $\mathrm{M}_{1}$-preferring receptor antagonist trihexyphenidyl produced full substitution for a $1.25 \mathrm{mg} / \mathrm{kg}$ (i.p.) clozapine training dose, although only partial substitution was found for a $5.0 \mathrm{mg} / \mathrm{kg}$ (i.p.) clozapine training dose in rats trained to discriminate clozapine from vehicle in twolever drug discrimination tasks. In a study by Porter et al. (2005) using rats trained to discriminate $1.0 \mathrm{mg} / \mathrm{kg}$ chlorpromazine versus $5.0 \mathrm{mg} / \mathrm{kg}$ clozapine versus vehicle (i.p.), scopolamine was found to produce partial substitution for chlorpromazine and full substitution for clozapine. Based on these findings, it is clear that antagonism of muscarinic receptors is sufficient to produce full generalization from clozapine's discriminative cue in rats. However, in other species, the role of muscarinic receptor blockade in the clozapine discriminative cue is less clear. In C57BL/6 mice (Philibin et al. 2005) and in DBA/2 mice (Porter et al. 2008) trained in a two-lever operant procedure to discriminate $2.5 \mathrm{mg} / \mathrm{kg}$ (s.c.) clozapine from vehicle, scopolamine produced only partial substitution for clozapine, while in pigeons trained in a two-key operant procedure to discriminate $1.0 \mathrm{mg} / \mathrm{kg}$ (i.m.) clozapine from vehicle, scopolamine (and atropine) failed to produce even partial substitution for clozapine (Hoenicke et al. 1992).

Although clozapine appears to be an antagonist or weak partial agonist in vivo, an active metabolite of clozapine, $\mathrm{N}$ desmethylclozapine, is a high affinity partial agonist for $\mathrm{M}_{1}$ muscarinic receptors (Davies et al. 2004; Weiner et al. 2004). $N$-desmethylclozapine does not substitute for clozapine in rats trained to discriminate $1.25 \mathrm{mg} / \mathrm{kg}$ (i.p.) clozapine from vehicle, although $\mathrm{N}$-desmethylclozapine produced full substitution when combined with a low dose of clozapine $(0.3125 \mathrm{mg} / \mathrm{kg})$ that did not substitute for the clozapine training dose (Prus et al. 2008). N-desmethylclozapine also failed to substitute for clozapine in rats trained to discriminate $1.25 \mathrm{mg} / \mathrm{kg}$ clozapine from $5.0 \mathrm{mg} / \mathrm{kg}$ clozapine from vehicle (i.p.; Prus et al. 2006). In C57B1/6 mice, $N$-desmethylclozapine also does not substitute for clozapine $(2.5 \mathrm{mg} / \mathrm{kg}$ training dose, s.c.; Philibin et al. 2008); however, as in the Prus et al. (2008) study, $N$ desmethylclozapine produced full substitution when combined with a low dose of clozapine $(0.625 \mathrm{mg} / \mathrm{kg})$ that did not substitute for the clozapine training dose.

Nicotinic cholinergic receptors do not appear to play a role in the discriminative stimulus properties of clozapine as it has been shown that nicotine does not substitute for $5.0 \mathrm{mg} / \mathrm{kg}$ (i.p.) clozapine in clozapine-trained rats and that clozapine does not substitute for $0.4 \mathrm{mg} / \mathrm{kg}$ (s.c.) nicotine in nicotine-trained rats (Villanueva et al. 1992) or $0.3 \mathrm{mg} / \mathrm{kg}$ (i.p.) nicotine (Brioni et al. 1994). Finally, the nicotinic receptor antagonist mecamylamine failed to substitute for either dose of clozapine in rats trained to discriminate $1.25 \mathrm{mg} / \mathrm{kg}$ versus $5.0 \mathrm{mg} / \mathrm{kg}$ clozapine versus vehicle (i.p.) in a threelever task (Prus et al. 2006).

\section{Serotonergic antagonism}

Hoenicke et al. (1992) have argued that the discriminative stimulus properties of clozapine are mediated by blockade of both 5- $\mathrm{HT}_{2 \mathrm{~A}}$ AND 5- $\mathrm{HT}_{2 \mathrm{C}}$ receptors. This suggestion was based on the results of a drug discrimination study with pigeons that were trained to discriminate $1.0 \mathrm{mg} / \mathrm{kg}$ (i.m.) clozapine from vehicle. They argued that the drugs that fully substituted for clozapine (cyproheptadine, metergoline, mianserin, pizotifen, and fluperlapine) block both 5$\mathrm{HT}_{2 \mathrm{~A}}$ and $5-\mathrm{HT}_{2 \mathrm{C}}$ receptors, but that the drugs that did not substitute for clozapine either had minimal or no serotonergic antagonism or that the drugs were selective for 5$\mathrm{HT}_{2 \mathrm{~A}}$ versus $5-\mathrm{HT}_{2 \mathrm{C}}$ receptors. This hypothesis also was supported by Philibin et al. (2005), who found that the 5$\mathrm{HT}_{2 \mathrm{~A} / 2 \mathrm{C}}$ receptor antagonist ritanserin produced full substitution in $\mathrm{C} 57 \mathrm{BL} / 6$ mice that were trained to discriminate $2.5 \mathrm{mg} / \mathrm{kg}$ (s.c.) clozapine from vehicle. However, there are differences between strains of mice as ritanserin does not substitute (either fully or partially) for $2.5 \mathrm{mg} / \mathrm{kg}$ (s.c.) 
clozapine in DBA/2 mice (Porter et al. 2008). Moreover, ritanserin does not substitute for clozapine in rats trained to discriminate $5.0 \mathrm{mg} / \mathrm{kg}$ (i.p.) clozapine from vehicle (Wiley and Porter 1992), $1.25 \mathrm{mg} / \mathrm{kg}$ clozapine from $5.0 \mathrm{mg} / \mathrm{kg}$ clozapine from vehicle (i.p.; Prus et al. 2006), $5.0 \mathrm{mg} / \mathrm{kg}$ clozapine from $0.03 \mathrm{mg} / \mathrm{kg}$ haloperidol (i.p.; Wiley and Porter 1993), or $5.0 \mathrm{mg} / \mathrm{kg}$ clozapine from chlorpromazine from vehicle (i.p.; Porter et al. 2005). Several studies also have reported that the serotonin antagonist ketanserin (a preferential $5-\mathrm{HT}_{2 \mathrm{~A}}$ antagonist with low activity at $5-\mathrm{HT}_{2 \mathrm{C}}$ receptors; Roth et al. 1992) does not substitute for clozapine in rats (Franklin and Tang 1994; Goudie et al. 1998c; Nielsen 1988; Tang et al. 1997) or in pigeons (Hoenicke et al. 1992) and that the highly selective $5-\mathrm{HT}_{2 \mathrm{~A}}$ antagonist MDL 100,907 (Sorensen et al. 1993) does not substitute for $5.0 \mathrm{mg} / \mathrm{kg}$ (i.p.) clozapine (Goudie et al. 1998c; Prus et al. 2004) or $1.25 \mathrm{mg} / \mathrm{kg}$ (i.p.) clozapine (Prus et al. 2004) in rats; although Millan et al. (1999) reported partial substitution for clozapine in rats. Also, it should be noted that clozapine (and other atypical antipsychotic drugs that preferentially bind to $5-\mathrm{HT}_{2 \mathrm{~A}}$ versus $\mathrm{D}_{2}$ receptors) fully substituted in rats trained to discriminate $0.16 \mathrm{mg} / \mathrm{kg}$ (i.p.) MDL 100,907 (Dekeyne et al. 2003), and clozapine (and the atypical antipsychotic drugs risperidone and sertindole) blocked the discriminative stimulus cue of the 5-HT $2 \mathrm{~A} / 2 \mathrm{C}$ agonist DOI ((2,5-dimethoxy-4-iodohenyl)2-aminopropan; Schreiber et al. 1994).

Antagonism of 5- $\mathrm{HT}_{3}$ receptors with MDL 72222 in rats (Wiley and Porter 1992, 1993) and ondansetron (GR38032F) in rats (Goudie et al. 1998c) and in pigeons (Hoenicke et al. 1992) does not generate clozapine-appropriate responding. Likewise, antagonism of $5-\mathrm{HT}_{2 \mathrm{~B} / 2 \mathrm{C}}$ receptors with $\mathrm{SB}$ 200646 or SDZ SER 082 does not produce clozapineappropriate responding in rats (Goudie et al.1998c; Millan et al. 1999). No substitution for clozapine has been found with the 5-HT $1 \mathrm{~A}$ agonists S-14506 in rats (Goudie et al. 1998c), 8-OH-DPAT in rats (Millan et al. 1999; Prus et al. 2006) or pigeons (Hoenicke et al. 1992), or buspirone (also a 5-HT $\mathrm{HA}_{1 \mathrm{~A}}$ agonist) in rats (Wiley and Porter 1992, 1993; Franklin and Tang 1994). Thus, while antagonism of $5-\mathrm{HT}_{2 \mathrm{~A} / 2 \mathrm{C}}$ receptors may be sufficient to produce clozapine-appropriate responding in pigeons (Hoenicke et al. 1992) and C57BL/6 mice (Philibin et al. 2005), this does not appear to be the case for rats trained to discriminate clozapine from vehicle. Also, antagonism or agonism of serotonergic receptors other than $5-\mathrm{HT}_{2 \mathrm{~A} / 2 \mathrm{C}}$ receptors does not appear to play a significant role in clozapine's discriminative cue for any of the species that have been tested.

\section{Dopaminergic antagonism}

The dopamine $\mathrm{D}_{1}$ antagonist $\mathrm{SCH} 23390$ does not substitute for clozapine in rats (Nielsen 1988; Villanueva et al. 1990; Franklin and Tang 1994; Porter et al. 1999; Prus et al. 2006) or in pigeons (Hoenicke et al. 1992). The $D_{1} / D_{5}$ antagonist SCH-39166 also does not substitute for clozapine in rats (Millan et al. 1999). Likewise, the $\mathrm{D}_{2}$ antagonist haloperidol fails to produce clozapine-appropriate responding in rats (Browne and Koe 1982; Ortmann et al. 1986; Villanueva et al. 1990; Wiley and Porter 1992, 1993; Franklin and Tang 1994; Millan et al. 1998; Goudie et al. 1998c; Goudie and Taylor 1998a; Porter et al. 1999; Tang et al. 1997; Prus et al. 2004, 2005a, b), C57BL/6 mice (Philibin et al. 2005), DNA/2 mice (Porter et al. 2008), or in squirrel monkeys (Carey and Bergman 1997). The $D_{2}$ antagonist sulpiride also was found to not substitute for clozapine in either rats (Ortmann et al. 1986) or pigeons (Hoenicke et al. 1992). Somewhat mixed results have been obtained with $\mathrm{D}_{3}$ antagonists. While the $\mathrm{D}_{3}$-preferring antagonist PNU-99194A fully substituted in rats trained to discriminate either $2.0 \mathrm{mg} / \mathrm{kg}$ (i.p.) or $5.0 \mathrm{mg} / \mathrm{kg}$ (i.p.) clozapine, four other $\mathrm{D}_{3}$ antagonists did not substitute for clozapine. Cross-generalization between clozapine and PNU99194A also was obtained as clozapine fully substituted in rats trained to discriminate $10.0 \mathrm{mg} / \mathrm{kg}$ (i.p.) PNU-99194A. However, these results might not be due to $\mathrm{D}_{3}$ antagonism as the muscarinic antagonists scopolamine and trihexyphenidyl also fully substituted for PNU-99194A (Goudie at al. 2001). Finally, the $\mathrm{D}_{4}$ receptor antagonist L-745,870 was found to not substitute for clozapine in rats (Goudie et al. 1998c).

Given that clozapine displays a relatively low affinity for dopamine receptors (Bymaster et al. 1996; Arnt and Skarsfeldt 1998), the inability of $D_{1}$ and $D_{2}$ antagonists to substitute for clozapine may reflect the relatively lowreceptor occupancy of dopamine receptors at the $5.0 \mathrm{mg} / \mathrm{kg}$ training dose that has typically been used. To address this issue, Porter et al. (1999) trained a group of rats to discriminate $10.0 \mathrm{mg} / \mathrm{kg}$ (i.p.) clozapine from vehicle, making the assumption that a greater percentage of dopamine receptors would be occupied at the higher training dose, as would be predicted by the occupation theory of drugreceptor action (Cooper et al. 1996). Testing with the $\mathrm{D}_{1}$ antagonist SCH 23390 and the $\mathrm{D}_{2}$ antagonist haloperidol revealed that the higher training dose of clozapine did not engender more clozapine-appropriate responding by either drug. Thus, blockade of dopamine receptors does not appear to play any significant role in mediating clozapine's discriminative stimulus properties. In fact, antagonism of dopamine $D_{2}$ receptors may inhibit the ability of some antipsychotic drugs to substitute for clozapine (see Cary and Bergman 1997; Cole et al. 2007).

Antagonism of other receptors

The $\alpha$ adrenergic antagonist phentolamine and the $\beta$ adrenergic antagonist propranolol do not substitute for 
clozapine in rats (Kelley and Porter 1997), and other studies have reported that the selective $\alpha_{1}$-adrenoceptor antagonist prazosin does not substitute for clozapine in rats (Nielsen 1988; Goudie et al. 1998c; Millan et al. 1999; Porter et al. 2005; Prus et al. 2006) or pigeons (Hoenicke et al. 1992), and that the selective $\alpha_{2}$-adrenoceptor antagonist yohimbine also does not substitute for clozapine in rats (Franklin and Tang 1994; Goudie et al. 1998c; Prus et al. 2006). Thus, blockade of adrenergic $\alpha$ and $\beta$ receptors does not appear to produce clozapine-appropriate responding in either rats or pigeons. However, it should be noted that prazosin does fully substitute for clozapine in C57BL/6 mice (Philibin et al. 2008), but not in DBA/2 mice (Porter et al. 2008). Likewise, antagonism of $\mathrm{H}_{1}$ histamine receptors with mepyramine (also known as pyrilamine) in rats (Goudie et al. 1998c) or pyrilamine in pigeons (Hoenicke et al. 1992), in rats (Porter et al. 2005; Prus et al. 2006), in C57BL/6 mice (Philibin et al. 2008), and in DBA/2 mice (Porter et al. 2008) does not engender clozapine-appropriate responding.

Kelley and Porter (1997) reported that NMDA does not substitute for clozapine, in contrast to a report by Schmidt and Volz (1992) that NMDA substituted in rats trained to discriminate clozapine from saline in a T-maze drug discrimination procedure. Also, Arnt (1997) reported that clozapine produced partial substitution in rats trained to discriminate NMDA from vehicle. Though unresolved, the interaction of NMDA glutamate receptors with clozapine's discriminative cue remains a possibility.

\section{Discriminative stimulus properties of other atypical antipsychotic drugs}

To date, three other clinically active atypical antipsychotic drugs have been used as training drugs in the drug discrimination procedure: olanzapine, quetiapine, and ziprasidone (an unsuccessful attempt was made to train zotepine (Goudie et al. 2004a)). All of these compounds exhibit a greater affinity for $5-\mathrm{HT}_{2 \mathrm{~A}}$ receptors over $\mathrm{D}_{2}$ receptors (Bymaster et al. 1996; Moore et al. 1992, 1993; Roth et al. 1994), but like clozapine, they have diverse binding profiles for other receptors (Schotte et al. 1996). Olanzapine (a thienobenzodiazepine derivative) is an atypical antipsychotic drug that has a receptor-binding profile similar to clozapine (a dibenzodiazepine derivative), but has a much higher affinity for $\mathrm{D}_{1}$ and $\mathrm{D}_{2}$ dopamine receptors. Ziprasidone has a high affinity for $5-\mathrm{HT}_{1 \mathrm{~A}}$ and $5-\mathrm{HT}_{7}$ receptors. These three antipsychotics have appreciable affinities for $\alpha_{1}$-adrenoceptors, but only olanzapine displays a strong affinity for muscarinic receptors (Schotte et al. 1996, Richelson 1999; Millan et al. 2000).

\section{Olanzapine}

In rats trained to discriminate $5.0 \mathrm{mg} / \mathrm{kg}$ (i.p.) clozapine from vehicle, olanzapine at a dose of $1.25 \mathrm{mg} / \mathrm{kg}$ (Moore et al. 1992, 1993) or $2.5 \mathrm{mg} / \mathrm{kg}$ (Millan et al. 1999; Goudie et al. 2007) produced full substitution for clozapine; although several studies have reported only partial substitution for clozapine with olanzapine in rats (Franklin and Tang 1994; Goudie and Taylor 1998a) and in squirrel monkeys (Carey and Bergman 1997). One possible explanation for the lack of full substitution to clozapine's cue in these studies is that response rate suppression produced by olanzapine's dopaminergic antagonism prevents high doses from being tested. Carey and Bergman (1997) found that when the ratesuppressing effects of olanzapine were blocked by the dopamine $\mathrm{D}_{2}$ agonist (+)-PHNO, olanzapine produced full clozapine-lever responding in squirrel monkeys (similar findings have been reported in rats; Goudie et al. 1998b). More recently, Cole et al. (2007) also found that olanzapine failed to substitute for clozapine in rats trained to discriminate $5.0 \mathrm{mg} / \mathrm{kg}$ (i.p.) clozapine from vehicle. However, when the $\mathrm{D}_{2 / 3}$ agonist quinpirole was co-administered with olanzapine, full substitution for clozapine was obtained. Unlike the Carey and Bergman (1997) study, however, quinpirole did not block the rate-suppressing effects of olanzapine. Thus, a second explanation offered by Cole et al. (2007) is that $D_{2 / 3}$ antagonism may inhibit the ability of drugs like olanzapine to substitute for clozapine. A third explanation may be related to the training dose of clozapine used with rats. Goudie et al. (1998a) and Goudie and Taylor (1998b) found that olanzapine produced only $38 \%$ generalization in rats trained with a $5.0-\mathrm{mg} / \mathrm{kg}$ training dose of clozapine; whereas, $75 \%$ generalization to clozapine was obtained with a $2.0-\mathrm{mg} / \mathrm{kg}$ (i.p.) clozapine training dose. Porter et al. (2000b) have confirmed this training dose effect, reporting that $1.0 \mathrm{mg} / \mathrm{kg}$ olanzapine produced $90.3 \%$ clozapine-appropriate responding in rats trained to discriminate a low $1.25 \mathrm{mg} / \mathrm{kg}$ (i.p.) dose of clozapine from vehicle. Interestingly, this training dose effect has also been found with the atypical antipsychotic drug zotepine. Goudie et al. (2004a) found that zotepine produced full substitution in rats trained to discriminate $2.0 \mathrm{mg} / \mathrm{kg}$ (i.p.) clozapine from vehicle, but not in rats trained to discriminate $5.0 \mathrm{mg} / \mathrm{kg}$ clozapine from vehicle. Finally, it should be noted that olanzapine does display cross-tolerance to the clozapine discriminative cue in rats trained to discriminate $5.0 \mathrm{mg} / \mathrm{kg}$ (i.p.) clozapine (Goudie et al. 2007).

Porter and Strong (1996) successfully trained rats to discriminate $0.5 \mathrm{mg} / \mathrm{kg}$ (i.p.) olanzapine from vehicle in a two-lever drug discrimination procedure for food reward. They found that the olanzapine generalization curve was dose-dependent, yielding an $\mathrm{ED}_{50}$ of $0.17 \mathrm{mg} / \mathrm{kg}$ and that the atypical antipsychotic clozapine fully substituted for 
olanzapine in a dose-dependent manner $\left(\mathrm{ED}_{50}=0.26 \mathrm{mg} / \mathrm{kg}\right)$. This was the first study to demonstrate that rats can be trained to discriminate olanzapine from vehicle in a twolever drug discrimination procedure, and this study also demonstrated that the generalization between olanzapine and clozapine is symmetrical.

In a second study (Porter et al. 2000a), the discriminative stimulus properties of olanzapine were examined more fully. Two groups of rats were trained to discriminate either $0.5 \mathrm{mg} / \mathrm{kg}$ (i.p.) olanzapine or $0.25 \mathrm{mg} / \mathrm{kg}$ (i.p.) olanzapine from vehicle in a two-lever drug discrimination procedure. While the olanzapine cue shares some similarities to clozapine's cue, it also differs significantly. The typical antipsychotics chlorpromazine and thioridazine fully substituted for olanzapine, whereas these drugs produce only partial substitution in clozapine-trained rats (e.g., Goas and Boston 1978; Browne and Koe 1982; Porter et al. 1999) and do not substitute for clozapine in pigeons (Hoenicke et al. 1992). It should be noted, however, that a recent study by Philibin et al. (2008) found that both chlorpromazine and thioridazine fully substituted in C57BL/6 mice. Similar to previous results with clozapine-trained rats (e.g., Goudie and Taylor 1998a; Porter et al. 1999), the typical antipsychotic haloperidol and the atypical antipsychotic risperidone did not substitute for olanzapine. Also, the muscarinic antagonist scopolamine produced olanzapine-appropriate responding for both training doses-a finding that replicates previous results in clozapine-trained rats (Nielsen 1988; Kelley and Porter 1997; Goudie et al. 1998c). In contrast to previous findings with clozapine-trained rats (Wiley and Porter 1992, 1993) was the finding that the 5$\mathrm{HT}_{2 \mathrm{~A} / 2 \mathrm{C}}$ antagonist ritanserin fully substituted for olanzapine at two doses $(2.0$ and $4.0 \mathrm{mg} / \mathrm{kg})$ in the $0.5-\mathrm{mg} / \mathrm{kg}$ training dose group, although it should be noted that ritanserin does fully substitute for clozapine in C57BL/6 mice (Philibin et al. 2008). Thus, it appears that the pharmacological mechanisms mediating olanzapine's discriminative stimulus properties are different from clozapine's in that antagonism of either muscarinic receptors OR $5-\mathrm{HT}_{2 \mathrm{~A} / 2 \mathrm{C}}$ receptors is sufficient to produce olanzapineappropriate responding. One possible explanation as to why ritanserin substitutes for olanzapine, but not for clozapine may be related to the differential affinities that olanzapine and clozapine display for $5-\mathrm{HT}_{2 \mathrm{~A}}$ and $\mathrm{D}_{2}$ receptors. While olanzapine and clozapine have similar binding affinities for $\mathrm{M}_{1}$ muscarinic receptors $\left(1.9 \mathrm{nM}, K_{\mathrm{i}}\right)$, olanzapine displays a slightly greater affinity for $5-\mathrm{HT}_{2 \mathrm{~A}}$ receptors $\left(4 \mathrm{nM}, K_{\mathrm{i}}\right)$ than does clozapine $\left(12 \mathrm{nM}, K_{\mathrm{i}}\right)$, and a much stronger affinity for dopamine $\mathrm{D}_{2}$ receptors $(11 \mathrm{nM}$ versus $125 \mathrm{nM}$, $K_{\mathrm{i}}$; Bymaster et al. 1996). Interestingly, while ritanserin is a very potent antagonist at $5-\mathrm{HT}_{2}$ receptors $\left(0.9 \mathrm{nM}, \mathrm{IC}_{50}\right)$, it also displays some activity at $\mathrm{D}_{2}$ receptors $\left(70 \mathrm{nM}, \mathrm{IC}_{50}\right.$; Leysen et al. 1985). Thus, the importance of dopamine antagonism for olanzapine's discriminative cue cannot be entirely dismissed, although the partial substitution shown by the potent dopamine antagonists haloperidol and raclopride suggests that dopaminergic involvement in olanzapine's cue is minimal at best. The importance of serotonergic antagonism in olanzapine's discriminative cue properties is also reinforced by the finding that the atypical antipsychotic sertindole fully substitutes for olanzapine in rats trained to discriminate $0.5 \mathrm{mg} / \mathrm{kg}$ olanzapine (Varvel et al. 1999). Sertindole displays a strong affinity for $5-\mathrm{HT}_{2 \mathrm{~A} / 2 \mathrm{C}}$ receptors (as well as $D_{2}, D_{3}$, and $\alpha_{1}$ receptors), but does not bind to muscarinic receptors (Schotte et al. 1996). The lack of full substitution by risperidone for olanzapine is somewhat surprising given the similarity between sertindole and risperidone's binding profiles (Schotte et al. 1996); however, risperidone's slightly greater affinity for $\mathrm{D}_{2}$ receptors $(3.3$ versus $7.4 \mathrm{nM}, K_{\mathrm{i}}$ ) may have caused a greater suppression of response rates and, thus, prevented full substitution for olanzapine. The role of $\alpha_{1}$ receptors in olanzapine's discriminative cue remains to be determined.

\section{Quetiapine}

In rats trained to discriminate $10.0 \mathrm{mg} / \mathrm{kg}$ (i.p.) quetiapine from vehicle in a two-lever drug discrimination task (Smith and Goudie 2002), full substitution for quetiapine was shown for the atypical antipsychotic drugs clozapine, olanzapine, and risperidone, but not amisulpride. The typical antipsychotic drugs haloperidol, chlorpromazine, and loxapine (however, there is some evidence that loxapine may have "atypical" properties; see Glazer 1999; Meltzer and Jayathilake 1999) failed to produce full or partial substitution for clozapine. In a second study in which rats were trained to discriminate $10.0 \mathrm{mg} / \mathrm{kg}$ (i.p.) quetiapine, the atypical antipsychotic drug zotepine produced a maximum of $54 \%$ quetiapine-appropriate responding (Goudie et al. 2004a). Finally, Goudie et al. (2004b) examined the underlying receptor mechanisms involved in the discriminative stimulus properties of quetiapine [rats trained to discriminate quetiapine $10.0 \mathrm{mg} / \mathrm{kg}$ (i.p.) from vehicle]. They reported that full substitution was produced by scopolamine, and partial substitution was found for prazosin. Drugs selective for $\alpha_{2}, \mathrm{H}_{1}, \mathrm{D}_{1}, \mathrm{D}_{2}, \mathrm{D}_{3}, 5-\mathrm{HT}_{1 \mathrm{~A}}$, $5-\mathrm{HT}_{2 \mathrm{~A}}, 5-\mathrm{HT}_{2 \mathrm{C}}, 5-\mathrm{HT}_{3}$, and benzodiazepine receptors failed to substitute for quetiapine. The ability of the muscarinic antagonist scopolamine to substitute for quetiapine is similar to the findings discussed previously for high-dose clozapine discrimination (Nielsen 1998; Kelley and Porter 1997; Goudie et al. 1998c; Millan 1999).

\section{Ziprasidone}

Recently, ziprasidone was established as a discriminative stimulus in rats trained to discriminate $0.2 \mathrm{mg} / \mathrm{kg}$ (i.p.) 
ziprasidone from vehicle in a two-lever drug discrimination task (Wood et al. 2007). Ziprasidone (0.05-0.4 mg/kg) produced full generalization for itself at $0.14,0.2$, and $0.4 \mathrm{mg} / \mathrm{kg}$ doses $\left(\mathrm{ED}_{50}=0.07 \mathrm{mg} / \mathrm{kg}\right)$, with statistically significant rate suppression observed from 0.1 to $0.4 \mathrm{mg} / \mathrm{kg}$ doses compared to vehicle. The atypical antipsychotic drugs clozapine, olanzapine, risperidone, quetiapine, and zotepine fully substituted for ziprasidone, while aripiprazole fell just short of full substitution with $78.8 \%$ ziprasidone-appropriate responding. The typical antipsychotic drug haloperidol failed to produce either full or partial substitution for ziprasidone. The $5-\mathrm{HT}_{2 \mathrm{~A} / 2 \mathrm{C}}$ antagonist ritanserin fully substituted for ziprasidone, while the muscarinic antagonist scopolamine produced partial substitution. This finding is in contrast to the findings for highdose clozapine discrimination in which scopolamine fully substitutes for clozapine, but ritanserin does not (Nielsen 1998; Kelley and Porter 1997; Goudie et al. 1998c; Millan 1999).

\section{Discriminative stimulus properties of the typical antipsychotic drugs chlorpromazine and haloperidol}

The first drug discrimination study to examine the nature of the discriminative cue of the typical antipsychotic chlorpromazine was discussed in detail earlier (Goas and Boston 1978). While haloperidol substituted for chlorpromazine in that study, suggesting that blockade of dopamine receptors may play a role in the discriminative stimulus properties of chlorpromazine, the atypical antipsychotic clozapine (which has a more diverse binding profile) also produced full substitution for chlorpromazine. In addition to potent antagonism of dopamine receptors, haloperidol does display moderate affinity for $5-\mathrm{HT}_{2 \mathrm{~A}}$ and $\alpha_{1}$ receptors (Schotte et al. 1996). The importance of dopaminergic antagonism for chlorpromazine's cue (and haloperidol's cue) is reinforced by the finding that chlorpromazine substitutes for haloperidol in rats trained to discriminate $0.05 \mathrm{mg} / \mathrm{kg}$ (i.p.) haloperidol from vehicle (McElroy et al. 1989); i.e., there was cross-generalization between chlorpromazine and haloperidol in those two studies. In rats trained to discriminate $1.0 \mathrm{mg} / \mathrm{kg}$ (i.p.) chlorpromazine from vehicle (Porter et al. 1998), the chlorpromazine cue fully generalized to the atypical antipsychotics clozapine and olanzapine and to the typical antipsychotic thioridazine, but only partially generalized to haloperidol (a typical antipsychotic) and to raclopride (an atypical antipsychotic). These results demonstrated that the cross-generalization between chlorpromazine and olanzapine is symmetrical, unlike the crossgeneralization between chlorpromazine and clozapine that is not symmetrical (Goas and Boston 1978). This suggests that the discriminative stimulus properties of chlorproma- zine and olanzapine may be more similar than those of chlorpromazine and clozapine. Also, it is not clear why haloperidol failed to fully substitute for chlorpromazine in this study as it did in the Goas and Boston (1978) study; however, differences in training dose and route of administration for chlorpromazine may account for this discrepancy.

While two studies (Colpaert et al. 1976; McElroy et al. 1988) have demonstrated that haloperidol can be established as the training drug in two-lever drug discrimination, substitution testing was only conducted in the McElroy et al. study and with only one drug, chlorpromazine. As mentioned above, chlorpromazine fully substituted for haloperidol ( $83 \%$ drug-lever responding). The importance of dopamine antagonism for the discriminative stimulus properties of haloperidol also was demonstrated by complete blockade of haloperidol's cue by the dopamine agonists, amphetamine and cocaine. A study with the highly selective $\mathrm{D}_{2 / 3}$ dopamine receptor antagonist tiapride (30 $\mathrm{mg} / \mathrm{kg}$, i.p.) demonstrated that dopamine antagonists can be established as the training drug in two-lever drug discrimination (Cohen et al. 1997). A number of typical (pimozide, chlorpromazine, haloperidol, and thioridazine) and atypical (olanzapine, raclopride, remoxipride, risperidone, and sulpiride) antipsychotic drugs produced dosedependent substitution for tiapride with one notable exception-clozapine. This finding further supports the lack of dopamine involvement in clozapine's discriminative cue and reinforces the idea that dopamine antagonism plays an important role in the discriminative stimulus properties of chlorpromazine and haloperidol and perhaps, to a lesser extent, in olanzapine's discriminative cue.

In order to further clarify differences in the discriminative stimulus properties of clozapine and chlorpromazine, Porter et al. (2005) trained rats to discriminate $5.0 \mathrm{mg} / \mathrm{kg}$ clozapine from $1.0 \mathrm{mg} / \mathrm{kg}$ chlorpromazine from vehicle (i.p.) in a three-lever drug discrimination task. There was some evidence of cross-generalization between clozapine and chlorpromazine in this three-lever discrimination as a $0.3125 \mathrm{mg} / \mathrm{kg}$ dose of clozapine produced full substitution for chlorpromazine, while a $4.0 \mathrm{mg} / \mathrm{kg}$ dose of chlorpromazine produced partial substitution for clozapine. Olanzapine $(0.015-4.0 \mathrm{mg} / \mathrm{kg})$ produced a similar substitution pattern, with lower olanzapine doses (0.06 and $0.125 \mathrm{mg} / \mathrm{kg}$ ) producing partial substitution for chlorpromazine and higher olanzapine doses $(2.0$ and $4.0 \mathrm{mg} / \mathrm{kg})$ producing partial substitution for clozapine. Scopolamine also produced this same pattern of substitution. Risperidone and haloperidol fully substituted for chlorpromazine, but not for clozapine. Of the selective receptor ligands tested, full substitution was only found for the $\alpha_{1}$ receptor antagonist prazosin for the chlorpromazine discriminative cue. 


\section{What is the pharmacological basis of the discriminative stimulus properties of antipsychotic drugs?}

It is obvious from the studies discussed above that there is no simple answer for this question. Also, there clearly are differences between the discriminative stimulus properties of the atypical antipsychotics clozapine, olanzapine, quetiapine, and ziprasidone and the typical antipsychotics chlorpromazine and haloperidol, even though there are shared mechanisms between these drugs. The majority of the research has been conducted with clozapine, and in rats, the only selective receptor antagonists that have consistently produced full substitution for clozapine are the muscarinic antagonists scopolamine (Nielsen 1988; Franklin and Tang 1994; Kelley et al. 1994; Kelley and Porter 1997; Goudie et al. 1998c; Millan et al. 1999), trihexyphenidyl (Kelley and Porter 1997), and atropine (Nielsen 1988). Thus, antagonism of muscarinic receptors clearly is sufficient to engender clozapine-appropriate responding in rats, but it may not be a necessary mechanism (i.e., antagonism of other receptors, either alone or in combination, may also be sufficient). The idea that a single receptor mediates clozapine's discriminative stimulus properties is complicated by the fact that drugs with a low affinity for muscarinic receptors have been shown to fully substitute for clozapine. For example, in the Kelley et al. (1997) study, mianserin produced full substitution in the clozapinetrained rats, but did not substitute for scopolamine. While mianserin has a high affinity for $5-\mathrm{HT}_{2 \mathrm{~A} / 2 \mathrm{C}}$ receptors (Jenck et al. 1994), it displays minimal affinity for muscarinic receptors (469 nM, $\mathrm{K}_{\mathrm{D}}$; Golds et al. 1980), although it may interact indirectly with muscarinic systems (see Kelley et al. 1995). The fact that sertindole and risperidone (which do not bind to muscarinic receptors; see Schotte et al. 1996) produced full substitution at a $1.25-\mathrm{mg} / \mathrm{kg}$ training dose of clozapine (Porter et al. 2000b) supports the conclusion that antagonism of other receptors (perhaps serotonergic?) must account for the ability of these two drugs to substitute at this low training dose (these drugs do not substitute for clozapine when a $5.0-\mathrm{mg} / \mathrm{kg}$ training dose is used; see Goudie and Taylor 1998a). Hoenicke et al. (1992) have argued that antagonism of $5-\mathrm{HT}_{2 \mathrm{~A}}$ and $5-\mathrm{HT}_{2 \mathrm{C}}$ mediates clozapine's discriminative cue in pigeons; although it should be noted that most of the drugs substituting for clozapine in that study also display a high affinity for muscarinic receptors (see Kelley et al. 1997). Finally, there is evidence that clozapine's discriminative cue in C57BL $/ 6$ mice may be mediated by antagonism at $5-\mathrm{HT}_{2 \mathrm{~A} / 2 \mathrm{C}}$ and $\alpha_{1}$ receptors (Philibin et al. 2005; 2008).

Another possibility is that clozapine's discriminative stimulus properties are mediated by a compound cue involving antagonism of two or more receptors. This possibility was first proposed by Franklin and Tang
(1994; see also Carey and Bergman 1997 and Tang et al. 1997; Millan et al. 1999; Porter et al. 2000b), and Goudie and his colleagues have argued strongly for this hypothesis (Goudie and Taylor 1998a; Goudie et al. 1998c; Goudie and Smith 1999). One interesting idea proposed by Goudie and his colleagues is that the clozapine cue may be a functional reflection of a mixture of simultaneous action at several different receptors. Given clozapine's diverse binding profile, this is not an unreasonable hypothesis. Research with drug mixtures (i.e., Drug A + Drug B) in drug discrimination studies has shown that if either Drug A or Drug B are given alone at a high enough dose they can fully substitute for the drug mixture (see Gauvin et al. 1998; Stolerman et al. 1994, 1996). It might be possible that the training dose of clozapine also changes the nature of this compound cue, since sertindole and risperidone substitute at a low clozapine training dose (i.e., $1.25 \mathrm{mg} / \mathrm{kg}$ ), but not at a higher training dose (i.e., $5.0 \mathrm{mg} / \mathrm{kg}$ ). Since these two drugs do not bind to muscarinic receptors, antagonism of another receptor(s) must be responsible for the full generalization to the clozapine cue seen at the lower training dose. Generalization to a compound cue also might be achieved by testing appropriate mixtures of selective ligands. However, given clozapine's diverse binding profile, testing mixtures of two or more ligands simultaneously will be a challenge given the number of possible combinations of selective receptor ligands that would have to be tested and given that the training dose of clozapine would also have to be considered. Some evidence of a compound cue for clozapine was demonstrated in a study conducted by Prus et al. (2004). In rats trained to discriminate $1.25 \mathrm{mg} / \mathrm{kg}$ (i.p.) clozapine from vehicle, the combination of the 5-HT $2 \mathrm{~A}$ receptor antagonist MDL 100,907 $(0.12 \mathrm{mg} / \mathrm{kg})$ with the typical antipsychotic drug and $\mathrm{D}_{2}$-receptor-preferring antagonist haloperidol $(0.1 \mathrm{mg} / \mathrm{kg})$ produced full substitution for clozapine (although with significant rate suppression), while neither of these drugs substituted for clozapine when tested alone.

Less is known about the mechanisms mediating the discriminative stimulus properties of other antipsychotic drugs. Muscarinic receptor antagonism appears to be important for the discriminative stimulus properties of olanzapine (Porter et al. 2000a), quetiapine (Goudie et al. 2004b), and chlorpromazine (Porter et al. 2005). However, olanzapine's cue clearly involves serotonergic receptors as well since ritanserin has been shown to fully substitute for olanzapine (Porter et al. 2000a). While the involvement of any other receptors in olanzapine's discriminative cue remains to be determined, these findings suggest that olanzapine also may have a compound cue. The limited information for chlorpromazine and haloperidol suggest that antagonism of dopamine receptors is sufficient to produce full generalization to their discriminative cues, 
although full substitution for chlorpromazine by prazosin suggests that $\alpha_{1}$ receptor blockade may also play an important role in mediating chlorpromazine's stimulus effects. Thus, while there are similarities among the discriminative stimulus properties of atypical and typical antipsychotics, there also are important differences in the mechanisms that mediate their discriminative cues.

\section{Predictive validity of drug discrimination with antipsychotic drugs}

If an animal model for antipsychotic drugs is to be useful, it must have predictive validity. While there are a number of different criteria that can be used to evaluate the validity and usefulness of a particular model (see Ellenbroek and Cools 1990; Ellenbroek 1993), perhaps the simplest is whether or not there are false positives and false negatives for the atypical and typical antipsychotic drugs tested in the model. In Table 2, the results of two-lever drug discrimination studies that have used an antipsychotic drug as the training drug are summarized. Table 2 also shows which antipsychotic drugs produce full substitution (defined as $80 \%$ or greater drug-appropriate responding), partial substitution (defined as drug-appropriate responding between $60 \%$ and $80 \%$ ), or no substitution (defined as less than $60 \%$ drug-appropriate responding) for the discriminative cue of each training drug. While there is no universal agreement as to what constitutes an atypical or novel antipsychotic drug (see Reynolds 1997; Arnt and Skarsfeldt 1998; Goudie and Smith 1999), both the training drugs and the test drugs have been classified as atypical or as typical antipsychotics based on the general consensus for each drug that is found in the literature.

The first thing that is obvious from a casual examination of Table 2 is that relatively little data is available with which to evaluate the validity of drug discrimination for drugs other than clozapine. In the two-choice drug discrimination procedure, only a small number of other antipsychotic drugs have been used as the training drug: two studies each have been conducted with chlorpromazine, with olanzapine, with quetiapine, and with haloperidol and only one study with ziprasidone. The typical antipsychotic chlorpromazine substitutes for both haloperidol (typical) and for olanzapine (atypical), but not for clozapine (atypical) in rats but does substitute for clozapine in C57BL/6 mice. The typical antipsychotic haloperidol substitutes for chlorpromazine, but not for atypical antipsychotics. The atypical antipsychotic clozapine produces full generalization both to olanzapine's discriminative cue and to chlorpromazine's discriminative cue (it has not been tested in haloperidoltrained animals), and olanzapine generalizes completely to both clozapine and chlorpromazine (it has not been tested in haloperidol-trained animals). Thus, there is clearly a great deal of overlap between the discriminative stimulus properties of clozapine, olanzapine, and chlorpromazine and between chlorpromazine and haloperidol. So far, the discriminative stimulus properties of quetiapine and ziprasidone appear to be relatively specific to atypical antipsychotic drugs, given that (with the exception of amisulpride that failed to substitute for quetiapine) all of the atypical antipsychotic drugs tested fully substitute for quetiapine and ziprasidone (except aripiprazole which produced strong partial substitution for ziprasidone); whereas, all typical antipsychotic drugs tested fail to fully or partially substitute for quetiapine or ziprasidone.

A large number of typical and atypical antipsychotic drugs have been tested in animals trained to discriminate clozapine from vehicle in rats, mice, pigeons, and monkeys. None of the typical antipsychotics tested to date have fully substituted for clozapine in rats with the exception of thioridazine, which was once considered an atypical antipsychotic drug before risks of tardive dyskinesia led to it being classified as a typical antipsychotic drug. Thus, with the exception of thioridazine, there are no false positives in the clozapine drug discrimination studies with rats for the typical antipsychotics that have been tested. In a recent clozapine drug discrimination with mice, however, Philibin et al. (2008) found that the typical antipsychotic drugs thioridazine and chlorpromazine both fully substituted for clozapine. Thus, there appear to be important differences between the rat and mouse drug discrimination assays for clozapine discrimination.

Results with atypical antipsychotics have not been as consistent. Two atypical antipsychotic drugs (risperidone and sertindole) have failed to substitute for clozapine, suggesting that there may a number of false negatives. However, a series of clozapine drug discrimination studies have recently shown that the training dose of clozapine may be critical when using this procedure as a screening model for atypical antipsychotic effects. Goudie and Taylor (1998b), Goudie et al. (1998a), Porter et al. (2000b), and Smith et al. (1998) have demonstrated that the atypical antipsychotics olanzapine, sertindole, risperidone, and zotepine generalize completely when a lower clozapine training dose $(1.25 \mathrm{mg} / \mathrm{kg}$ or $2.0 \mathrm{mg} / \mathrm{kg})$ in rats is used and that typical antipsychotics still do not generalize to clozapine's cue. While these results are encouraging, the atypical antipsychotics quetiapine (Porter et al. 2000b) and ziprasidone (Prus et al. 2005b) produce only partial substitution for a $1.25-\mathrm{mg} / \mathrm{kg}$ clozapine training dose, yet fully substitute for a $5.0-\mathrm{mg} / \mathrm{kg}$ clozapine training dose (Prus et al. 2005b). However, establishing both of these doses of clozapine as discriminative stimuli in the same rats did not improve the selectivity of this procedure as risperidone produced partial substitution, and ziprasidone 
Table 2 A summary of results for two-lever drug discrimination studies in which the training drug was an antipsychotic drug

\begin{tabular}{|c|c|c|c|c|c|c|}
\hline \multirow[t]{2}{*}{ Test drug } & \multicolumn{6}{|l|}{ Training Drug } \\
\hline & Clozapine & Olanzapine & Quetiapine & Ziprasidone & Chlorpromazine & Haloperidol \\
\hline \multicolumn{7}{|l|}{ Atypicals } \\
\hline Amisulpride & $\mathrm{No}^{\mathrm{D}}$ & & $\mathrm{No}^{\mathrm{X}}$ & & & \\
\hline Aripiprazole & $\mathrm{No}^{\mathrm{DD}, \mathrm{EE}}$ & & & Full $^{\mathrm{Z}}$ & & \\
\hline Clozapine & - & Full $^{\mathrm{M}, \mathrm{N}}$ & Full $^{\mathrm{X}}$ & Full $^{\mathrm{Z}}$ & $\mathrm{Full}^{\mathrm{O}, \mathrm{P}}$ & \\
\hline Fluperlapine & Full $^{\mathrm{A}, \mathrm{B}, \mathrm{C}}$ & & & & & \\
\hline Iloperidone & Full $^{\mathrm{DD}}$ & & & & & \\
\hline Melperone & Full $^{\mathrm{BB}, \mathrm{DD}}$ & & & & & \\
\hline Olanzapine & $\begin{array}{l}\text { Full }{ }^{\mathrm{C}, \mathrm{E}, \mathrm{F}, \mathrm{G}, \mathrm{H}, \mathrm{AA}, \mathrm{CC}, \mathrm{EE}, \mathrm{FF}, \mathrm{GG}} \\
\text { Partial }^{\mathrm{i}} \\
\mathrm{No}^{\mathrm{C}, \mathrm{D}}\end{array}$ & - & Full $^{\mathrm{X}}$ & Full $^{\mathrm{Z}}$ & Full $^{\mathrm{P}}$ & \\
\hline Remoxipride & $\mathrm{No}^{\mathrm{C}, \mathrm{G}}$ & & & & & \\
\hline Risperidone & $\begin{array}{l}\text { Full }^{\mathrm{G}, \mathrm{CC}, \mathrm{EE}} \\
\text { Partial }^{\mathrm{AA}} \\
\mathrm{No}^{\mathrm{c}, \mathrm{D}, \mathrm{FF}}\end{array}$ & Partial $^{\mathrm{N}}$ & Full $^{\mathrm{X}}$ & Full $^{\mathrm{Z}}$ & & \\
\hline Quetiapine & $\begin{array}{l}\text { Full }^{\mathrm{C}, \mathrm{D}, \mathrm{AA}, \mathrm{DD}, \mathrm{FF}} \\
\text { Partial }^{\mathrm{G}}\end{array}$ & & - & Full $^{\mathrm{Z}}$ & & \\
\hline Sertindole & $\begin{array}{l}\text { Full }^{\mathrm{G}, \mathrm{DD}} \\
\text { Partial }^{\mathrm{D}, \mathrm{AA}} \\
\mathrm{No}^{\mathrm{C}, \mathrm{FF}}\end{array}$ & & & & & \\
\hline Sulpiride & $\mathrm{No}^{\mathrm{B}, \mathrm{K}}$ & & & & & \\
\hline Ziprasidone & $\begin{array}{l}\text { Full }^{\mathrm{AA}, \mathrm{CC}} \\
\text { Partial }^{\mathrm{EE}} \\
\mathrm{No}^{\mathrm{FF}}\end{array}$ & & & - & & \\
\hline Zotepine & $\begin{array}{l}\text { Full } \\
\text { Partial }^{\mathrm{L}, \mathrm{DD}}\end{array}$ & & & Full $^{\mathrm{Z}}$ & & \\
\hline \multicolumn{7}{|l|}{ Typicals } \\
\hline Chlorpromazine & $\begin{array}{l}\text { Full }^{\mathrm{DD}} \\
\text { Partial }^{\mathrm{D}, \mathrm{O}} \\
\mathrm{No}^{\mathrm{B}, \mathrm{G}, \mathrm{AA}}\end{array}$ & Full $^{\mathrm{N}}$ & $\mathrm{No}^{\mathrm{X}}$ & & - & FULL $^{\mathrm{W}}$ \\
\hline Clotiapine & $\mathrm{No}^{\mathrm{C}}$ & & & & & \\
\hline Fluphenazine & $\mathrm{No}^{\mathrm{G}, \mathrm{AA}}$ & & & & & \\
\hline Haloperidol & $\mathrm{No}^{\mathrm{C}, \mathrm{F}, \mathrm{I}, \mathrm{J}, \mathrm{K}, \mathrm{O}, \mathrm{Q}, \mathrm{R}, \mathrm{S}, \mathrm{T}, \mathrm{U}, \mathrm{AA}, \mathrm{BB}, \mathrm{CC}, \mathrm{HH}}$ & Partial $^{\mathrm{N}}$ & $\mathrm{No}^{\mathrm{X}}$ & $\mathrm{No}^{\mathrm{Z}}$ & $\begin{array}{l}\mathrm{Full}^{\mathrm{O}} \\
\mathrm{No}^{\mathrm{P}}\end{array}$ & - \\
\hline & Partial ${ }^{\mathrm{G}, \mathrm{EE}}$ & & & & & \\
\hline Loxapine & $\mathrm{No}^{\mathrm{C}, \mathrm{D}, \mathrm{J}}$ & & $\mathrm{No}^{\mathrm{X}}$ & & & \\
\hline Mezilamine & $\mathrm{No}^{\mathrm{J}}$ & & & & & \\
\hline Raclopride & & $\operatorname{Partial}^{\mathrm{N}}$ & $\mathrm{No}^{\mathrm{Y}}$ & & $\mathrm{No}^{\mathrm{P}}$ & \\
\hline Thioridazine & $\begin{array}{l}\text { Full }^{\mathrm{AA}, \mathrm{DD}} \\
\text { Partial }^{\mathrm{G}, \mathrm{I}, \mathrm{J}, \mathrm{T}, \mathrm{U}} \\
\mathrm{No}^{\mathrm{B}, \mathrm{C}, \mathrm{D}, \mathrm{V}}\end{array}$ & $\begin{array}{l}\text { Full }^{\mathrm{N}} \\
\text { Partial }^{\mathrm{N}}\end{array}$ & & & Full $^{\mathrm{P}}$ & \\
\hline
\end{tabular}

Substitution for the discriminative cue of the training drug is shown only for the atypical and typical antipsychotic drugs tested in these studies. FULL substitution is defined as $>80 \%$ drug-appropriate responding; PARTIAL substitution is defined as drug-appropriate responding $>60 \%$ and $<80 \%$; and NO substitution is defined as $<60 \%$ drug-appropriate responding. Rats were used as the subjects in all of the studies cited except for four studies, which are noted below in the citations.

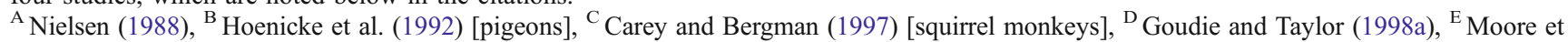
al. (1992), ${ }^{\mathrm{F}}$ Moore et al. (1993), ${ }^{\mathrm{G}}$ Porter et al. (2000b), ${ }^{\mathrm{H}}$ Goudie and Taylor (1998b), ${ }_{\mathrm{I}}$ Franklin and Tang (1994), ${ }^{\mathrm{J}}$ Browne and Koe (1982), ${ }^{\mathrm{K}}$ Ortmann et al. (1986), ${ }^{\mathrm{L}}$ Smith et al. (1998), ${ }^{\mathrm{M}}$ Porter and Strong (1996), ${ }^{\mathrm{N}}$ Porter et al. (2000), ${ }^{\mathrm{O}}$ Goas and Boston (1978), ${ }^{\mathrm{P}}$ Porter et al. (1998), ${ }^{Q}$ Ortmann et al. (1986), ${ }^{\mathrm{R}}$ Wiley and Porter (1992), ${ }^{\mathrm{S}}$ Tang et al. (1997), ${ }^{\mathrm{T}}$ Goudie et al. (1998c), ${ }^{\mathrm{U}}$ Porter et al. (1999), ${ }^{\mathrm{V}}$ Kelley and Porter (1997),

${ }^{\mathrm{W}}$ McElroy et al. (1989), ${ }^{\mathrm{X}}$ Smith and Goudie (2002), ${ }^{\mathrm{Y}}$ Goudie et al (2004), ${ }^{\mathrm{Z}}$ Wood et al. (2007), ${ }^{\mathrm{AA}}$ Prus et al. (2005b), ${ }^{\mathrm{BB}}$ Prus et al. (2004), ${ }^{\mathrm{CC}}$ Philibin et al. (2005) [C57BL/6 mice], ${ }^{\mathrm{DD}}$ Philibin et al. (2008, This Issue) [C57BL/6 mice], ${ }^{\mathrm{EE}}$ Porter et al. (2008) [DBA/2 mice], ${ }^{\mathrm{FF}} \mathrm{Millan}$ et al. (1999), ${ }^{\mathrm{GG}}$ Goudie et al. (2007), ${ }^{\mathrm{HH}}$ Millan et al. (1998) 
produced no substitution for either dose of clozapine in rats trained to discriminative $1.25 \mathrm{mg} / \mathrm{kg}$ clozapine from $5.0 \mathrm{mg} / \mathrm{kg}$ clozapine from vehicle in a three-lever drug discrimination task (Prus et al. 2005a). The fact that the training dose affects the validity of this model reinforces the idea that behavioral variables are critical in behavioral pharmacology research and that refinement of behavioral models can lead to a better understanding of the behavioral and pharmacological effects of drugs. Another important factor related to the training doses used in drug discrimination studies is their relevance to clinical doses. While this is sometimes difficult to determine, one study by Kapur et al. (2003) addressed this issue by examining the in vivo occupancy of dopamine $\mathrm{D}_{2}$ receptors in rats for a number of antipsychotic drugs. Interestingly, they found with acute dosing (s.c. injection route that avoided first-pass metabolism) that clozapine $(5-15 \mathrm{mg} / \mathrm{kg})$, olanzapine $(1-2 \mathrm{mg} / \mathrm{kg})$, risperidone $(0.5-1 \mathrm{mg} / \mathrm{kg})$, quetiapine $(10-25 \mathrm{mg} / \mathrm{kg})$, and haloperidol $(0.04-0.08 \mathrm{mg} / \mathrm{kg})$ reached clinically relevant levels of receptor occupancy. While $\mathrm{D}_{2}$ receptor occupancy is probably not the most relevant factor for drug discrimination with antipsychotic drugs (as discussed previously), these doses are clearly in the dose ranges that are typically used in drug discrimination studies.

\section{Conclusions}

Contrary to early reports about the difficulty of establishing antipsychotics as training drugs in drug discrimination studies, a growing literature is demonstrating that drug discrimination studies (especially with the atypical antipsychotic clozapine) can provide valuable information about the similarities and differences among typical and atypical antipsychotic drugs. While clozapine drug discrimination has already become an important preclinical assay in the development of new antipsychotic drugs, it will become even more useful as the importance of behavioral variables (i.e., training dose, species) in this model is better understood. These refinements in the model should increase its predictive validity. Also, as a better understanding of the neuropathology of schizophrenia and the relationship between symptoms and neurotransmitter systems is obtained, it may be possible to develop drug discrimination models (like low-dose clozapine discrimination and mouse-drug discrimination assays) that can help in the development of new antipsychotic drugs for the treatment of schizophrenia. Finally, it must be noted that the relationship between the discriminative stimulus properties of typical and atypical antipsychotics and their therapeutic effects in schizophrenic patients remains to be determined.

\section{References}

Arnt $\mathrm{J} \alpha_{1}$-adrenoceptor antagonists substitute for the discriminative stimulus properties of NMDA in rats. Poster presented at the meeting of the Society for Neuroscience, New Orleans, October 1997

Arnt J, Skarsfeldt T (1998) Do novel antipsychotics have similar pharmacological characteristics? A review of the evidence. Neuropsychopharmacology 18:63-101

Barry H III, Steenberg ML, Manian AA, Buckley JP (1974) Effects of chlorpromazine and three metabolites on behavioral responses in rats. Psychopharmacology (Berlin) 34:351-360

Brioni JD, Kim DJB, O’Neill AB, Williams JEG, Decker MW (1994) Clozapine attenuates the discriminative stimulus properties of (-)nicotine. Brain Res 643:1-9

Browne RG, Koe BK (1982) Clozapine and agents with similar behavioral and biochemical properties. In: Colpaert FC, Slangen JL (eds) Drug discrimination: applications in CNS pharmacology. Elsevier Biomedical, Amsterdam, pp 241-254

Bymaster FP, Calligaro DO, Falcone JF, Marsh RD, Moore NA, Tye NC, Seeman P, Wong DT (1996) Radioreceptor binding profile of the atypical antipsychotic olanzapine. Neuropsychopharmacology 14:87-96

Carey GJ, Bergman J (1997) Discriminative-stimulus effects of clozapine in squirrel monkeys: comparison with conventional and novel antipsychotic drugs. Psychopharmacology 132:261269

Casey E (1989) Clozapine: neuroleptic-induced EPS and tardive dyskinesia. Psychopharmacology 99:S47-S53

Claghorn J, Honigfeld G, Abuzzanab FS, Wang R, Steinbook R, Tauson V, Klerman G (1987) The risks and benefits of clozapine versus chlorpromazine. J Clin Psychopharmacol 7:377-384

Cohen C, Sanger DJ, Perrault G (1997) Characterization of the discriminative stimulus produced by the dopamine antagonist tiapride. J Pharmacol Exp Ther 283:566-573

Cole JC, Field M, Sumnall HR, Goudie AJ (2007) Potentiation of olanzapine substitution in rats discriminating clozapine by the D2/3 agonist quinpirole. Behav Pharmacol 18(3):185-190

Colpaert FC (1999) Drug discrimination in neurobiology. Pharmacol Biochem Behav 64(2):337-345

Colpaert FC, Niemegeers CJE, Janssen PAJ (1976) Theoretical and methodological considerations on drug discrimination learning. Psychopharmacologia (Berl.) 46:169-177

Cooper JR, Bloom FE, Roth RH (1996) The biochemical basis of neuropharmacology. Oxford University Press, New York, p 92

Crow T (1987) Positive and negative symptoms in schizophrenia. In: Henn FA, DeLisi LE (eds) Neurochemistry and neuropharmacology of Schizophrenia. Elsevier Science, New York, pp 178-189

Davies MA, Compton-Toth BA, Hufeisen SJ, Meltzer HY, Roth BL (2004) The highly efficacious actions of $N$-desmethylclozapine at muscarinic receptors are unique and not a common property of either typical or atypical antipsychotic drugs: is $M(1)$ agonism a pre-requisite for mimicking clozapine's actions? Psychopharmacology 178:451-460

Dekeyne A, Iob L, Millan MJ (2003) Generalization of clozapine as compared to other antipsychotic agents to a discriminative stimulus elicited by the serotonin $(5-\mathrm{HT})_{2 \mathrm{~A}}$ antagonist, MDL100,907. Neuropharmacology 44:604-615

Dolder C, Nelson M, Deyo Z (2008) Paliperidone for schizophrenia. Am J Health-Syst Pharm 65:403-413

Dlugosz H, Nasrallah HA (2007) Paliperidone: a new extendedrelease oral atypical antipsychotic. Expert Opin Pharmacother 8:2307-2313 
Ellenbroek BA (1993) Treatment of schizophrenia: a clinical and preclinical evaluation of neuroleptic drugs. Pharmac Ther 57:178

Ellenbroek BA, Cools A (1990) Animals models with construct validity for schizophrenia. Behav Pharmacol 1:469-490

Franklin SR, Tang AH (1994) Discriminative stimulus effects of clozapine in rats. Behav Pharmacol 5:113

Gauvin D, Vanacek SA, Baird TJ, Briscoe RJ, Carl KL, Holloway FA, Sannerud CA (1998) The stimulus properties of two common over-the-counter drug mixtures: dextromethorphan + ephedrine and dextromethorphan + diphenhydramine. J Psychopharmacol 12:84-92

Geyer MA, Ellenbroek B (2003) Animal behavior models of the mechanisms underlying antipsychotic atypicality. Progress Neuro-Psychopharmacol \& Biol Psychiatry 27:1071-1079

Glazer WM (1999) Does loxapine have "atypical" properties? Clinical evidence. J Clin Psychiatry 60(Suppl 10):42-46

Goas JA, Boston JE Jr (1978) Discriminative stimulus properties of clozapine and chlorpromazine. Pharmacol Biochem Behav 8: 235-241

Golds PR, Przyslo FR, Strange PG (1980) The binding of some antidepressant drugs to brain muscarinic acetylcholine receptors. British J Pharmacol 68:541-549

Goudie AJ, Smith JA (1999) Discriminative stimulus properties of antipsychotics. Pharmacol Biochem Behav 64(2):193-201

Goudie AJ, Taylor A (1998a) Comparative characterisation of the discriminative stimulus properties of clozapine and other antipsychotics in rats. Psychopharmacology 135:392-400

Goudie AJ, Taylor A (1998b) Olanzapine generalisation to the clozapine discriminative stimulus is determined by clozapine training dose. British J Pharmacol 124S:54

Goudie AJ, Taylor MAI, Smith JA (1998a) Stimulus properties of clozapine and related agents in rats at two clozapine training doses. J Psychopharmacol 12(Suppl):226

Goudie AJ, Taylor MAI, Smith JA (1998b) Converting olanzapine into clozapine in rats. J Psychopharmacol 12(Suppl):A57

Goudie AJ, Smith JA, Taylor A, Taylor MAI, Tricklebank MD (1998c) Discriminative stimulus properties of the atypical neuroleptic clozapine in rats: tests with subtype selective receptor ligands. Behav Pharmacol 9:699-710

Goudie AJ, Baker LE, Smith JA, Prus AJ, Svensson KA, CortesBurgos LA, Wong EHF, Haadsma-Svensson S (2001) Common discriminative stimulus properties in rats of muscarinic antagonists, clozapine and the $\mathrm{D}_{3}$ preferring antagonist PNU-99194A: an analysis of possible mechanisms. Behav Pharmacol 12:303315

Goudie AJ, Smith JA, Cole JC (2004a) Stimulus properties of the "atypical" antipsychotic zotepine in rats: comparisons with clozapine and quetiapine. Pharmacol Biochem Behav 77:163173

Goudie AJ, Smith JA, Millan MJ (2004b) Characterization of the effects of receptor-selective ligands in rats discriminating the novel antipsychotic quetiapine. Psychopharmacology 171:212222

Goudie AJ, Cooper GD, Cole JC, Sumnall HR (2006) Cyproheptadine resembles clozapine in vivo following both acute and chronic administration in rats. J Psychopharmacol 21(2):179-190

Goudie AJ, Cole JC, Sumnall HR (2007) Olanzapine and JL13 induce cross-tolerance to the clozapine discriminative stimulus in rats. Behav Pharmacol 18:9-17

Harris RT, Balster RL (1971) An analysis of the function of drugs in the stimulus control of operant behavior. In: Thompson $\mathrm{T}$, Pickens R (eds) Stimulus properties of drugs. Meredith, New York, NY, pp 111-132

Hoenicke EM, Vanecek SA, Woods JH (1992) The discriminative stimulus effects of clozapine in pigeons: involvement of 5- hydroxytryptamine-1c and 5-hydroxytryptamine-2 receptors. J Pharmacol Exp Ther 263:276-284

Honigfeld G, Patin J, Singer J (1984) Clozapine: antipsychotic activity in treatment-resistant schizophrenics. Adv Ther 1:77-97

Imperato A, Dazzi L, Obinu MC, Gessa GL, Biggio G (1994) The benzodiazepine receptor antagonist flumazenil increases acetylcholine release in rat hippocampus. Brain Res 647:167-171

Jenck F, Moreau J-L, Mutel V, Martin JR (1994) Brain 5-HT 1 C receptors and antidepressants. Prog Neuropsychopharmacol Psychiatry 18:563-574

Kane J, Honigfeld G, Singer J, Meltzer H (1988) Clozapine for the treatment-resistant schizophrenic: a double-blind comparison versus chlorpromazine/benztropine. Arch Gen Psychiatry 45: 789-796

Kapur S, Vanderspek SC, Brownlee BA, Nobrega JN (2003) Antipsychotic dosing in preclinical models is often unrepresentative of the clinical condition: a suggested solution based on in vivo occupancy. J Pharmacol Exp Ther 305:625-631

Kelley BM, Porter JH (1997) The role of muscarinic cholinergic receptors in the discriminative stimulus properties of clozapine in rats. Pharmacol Biochem Behav 57:707-719

Kelley BM, Nuti KA, Porter JH (1994) Further evidence for muscarinic antagonism as clozapine's discriminative stimulus. Society for Neuroscience Abstracts 20:1637

Kelley BM, Porter JH, Varvel SA (1995) Mianserin as a discriminative stimulus in rats: asymmetrical cross-generalization with scopolamine. Psychopharmacology 120:491-493

Lewis S, Lieberman J (2008) CATIE and CUtLASS: can we handle the truth? Br J Psychiatry 192:161-163

Leysen JE, Gommeren W, Van Gompel P, Wynants J, Janssen PFM, Laduron PM (1985) Receptor-binding properties in vitro and in vivo of ritanserin: a very potent and long acting serotonin- $\mathrm{S}_{2}$ antagonist. Mol Pharmacol 27:600-611

Li Z, Huang M, Ichikawa J, Dai J, Meltzer HY (2005) $\mathrm{N}$ desmethylclozapine, a major metabolite of clozapine, increases cortical acetylcholine and dopamine release in vivo via stimulation of M1 muscarinic receptors. Neuropsychopharmacology 30: $1986-1995$

Lieberman JA, Saltz BL, Johns CA, Pollack S, Kane J (1989) Clozapine effects on tardive dyskinesia. Psychopharmacol Bull 25:57-62

McElroy JF, Stimmel JJ, O'Donnell JM (1989) Discriminative stimulus properties of haloperidol. Drug Dev Res 18:47-55

Meert TF (1991) Application of drug discrimination with drugs of abuse to develop new therapeutic agents. In: Glennon RA, Jarbe TUC, Frankenheim J (eds) Drug discrimination: application to drug abuse research. NIDA (Research Monograph 116), Rockville, MD, pp 307-323

Meltzer HY (1992) The mechanism of action of clozapine in relation to its clinical advantages. In: Meltzer HY (ed) Novel antipsychotic drugs. Raven, New York, pp 1-13

Meltzer HY, Luchins DJ (1984) Effects of clozapine in severe tardive dyskinesia: a case report. J Clin Psychopharmacol 4:316-322

Meltzer HY, Jayathilake K (1999) Low-dose loxapine in the treatment of schizophrenia: is it more effective and more "atypical" than standard-dose loxapine? J Clin Psychiatry 60(Suppl 10):47-51

Meltzer HY, McGurk SR (1999) The effects of clozapine, risperidone, and olanzapine on cognitive function in schizophrenia. Schizo Bull 25(2):233-255

Meltzer HY, Matsubara S, Lee JC (1989) Classification of typical and atypical antipsychotic drugs on the basis of dopamine D-1, D-2 and serotonin $2 \mathrm{p} K \mathrm{i}$ values. J Pharmacol Exp Ther 251:238-46

Meyer JM (2007) Antipsychotic safety and efficacy concerns. J Clin Psychiatry 68(Suppl 14):20-26

Millan MJ (2000) Improving the treatment of Schizophrenia: focus on Serotonin (5-HT) ${ }_{1 \mathrm{~A}}$ Receptors. J Pharmacol Exp Ther 295:853861 
Millan MJ, Schreiber R, Dekeyne A, Rivet JM, Bervoets K, Mavridis M, Sebban C, Maurel-Remy S, Newman-Tancredi A, Spedding M, Muller O, LaVielle G, Brocco M (1998) S 16924 ((R)-2-\{1[2,3-dihydro-benzo[1,4] dioxin-5-yloxy)-ethyl]-pyrrolidin-3yl\}1-(4-fluoro-phenyl)-ethanone), a novel, potential antipsychotic with marked serotonin $(5-\mathrm{HT})_{1 \mathrm{~A}}$ agonist properties: II. functional profile in comparison to clozapine and haloperidol. J Pharmacol Exp Ther 286:1356-1373

Millan MJ, Schreiber R, Monneyron S, Denorme B, Melon C, Queriaux S, Dekeyne A (1999) S-16924, a novel, potential antipsychotic with marked serotonin ${ }_{1 \mathrm{~A}}$ agonist properties. IV. a drug discrimination comparison with clozapine. J Pharmacol Exp Ther 289:427-436

Millan MJ, Brocco M, Rivet JM, Audinot V, Newman-Tancredi A, Maiofiss L, Queriaux S, Despaux N, Peglion JL, Dekeyne A (2000) S18327 (1-[2-[4-(6-fluoro-1, 2-benzisoxazol-3-yl)piperid1-yl]ethyl]3-phenyl imidazolin-2-one), a novel, potential antipsychotic displaying marked antagonist properties at alpha(1)- and alpha(2)-adrenergic receptors: II. Functional profile and a multiparametric comparison with haloperidol, clozapine, and 11 other antipsychotic agents. J Pharmacol Exp Ther 292:54-66

Möller HJ (2003) Amisulpride: limbic specificity and the mechanism of antipsychotic atypicality. Prog Neuropsychopharmacol Biol Psychiatry 27(7):1101-1111

Moore NA, Tye NC, Axton MS, Risius FC (1992) The behavioral pharmacology of olanzapine, a novel "atypical" antipsychotic agent. J Pharmacol Exp Ther 262:545-551

Moore NA, Calligaro DO, Wong DT, Bymaster F, Tye NC (1993) The pharmacology of olanzapine and other new antipsychotic agents. Cur Opin Invest Drugs 2:281-293

Newman-Tancredi A, Assie M-B, Leduc N, Ormiere A-M, Danty N, Cosi C (2005) Novel antipsychotics activate recombinant human and native rat serotonin 5-HT1A receptors: affinity, efficacy and potential implications for treatment of schizophrenia. Int $\mathrm{J}$ Neuropsychopharmacology. 8:1-16

Nielsen EB (1988) Cholinergic mediation of the discriminative stimulus properties of clozapine. Psychopharmacology 94:115-118

Ortmann R, Meisburger JG, Bischoff S, Hauser K, Bittiger H, Waldmeier PC (1986) The clozapine cue in rats as tools for the characterization of neuroleptics. Psychopharmacology 89:S47, (Abstract)

Overton DA (1966) State dependent learning produced by depressant and atropine-like drugs. Psychopharmacology (Berlin) 10:6-31

Overton DA (1982) Comparison of the degree of discriminability of various drugs using the T-maze drug discrimination paradigm. Psychopharmacology 76:385-395

Philibin SD, Prus AJ, Pehrson AL, Porter JH (2005) Serotonin receptor mechanisms mediate the discriminative stimulus properties of the atypical antipsychotic clozapine in C57BL/6 mice. Psychopharmacology (Berl) 180(1):49-56

Philibin SD, Walentiny DM, Vunck SA, Prus, Meltzer HY, Porter JH (2008) Further characterization of the discriminative stimulus properties of the atypical antipsychotic drug clozapine in C57BL/ 6 mice. Psychopharmacology (this issue)

Porter JH, Strong SE (1996) Discriminative stimulus control with olanzapine: generalization to the atypical antipsychotic clozapine. Psychopharmacology 128:216-219

Porter JH, Covington HE III, Varvel SA, Vann RE, Warren TA (1998) Chlorpromazine as a discriminative stimulus in rats: generalization to typical and atypical antipsychotic. Drug Dev Res 48:38-44

Porter JH, Villanueva HF, Rosecrans JA (1999) The role of $\mathrm{D}_{1}$ and $\mathrm{D}_{2}$ dopamine receptors in the discriminative stimulus properties of the atypical antipsychotic clozapine in rats. Drug Dev Res 46:139-147

Porter JH, McCallum SE, Varvel SA, Vann RE (2000a) The discriminative stimulus properties of the atypical antipsychotic olanzapine in rats. Psychopharmacology 148:224-233
Porter JH, Varvel SA, Vann RE, Philibin SD, Wise LE (2000b) Clozapine drug discrimination with a low training dose distinguishes atypical from typical antipsychotic drugs in rats. Psychopharmacology 149:189-193

Porter JH, Prus AJ, Vann RE, Varvel SA (2005) Discriminative stimulus properties of the atypical antipsychotic clozapine and the typical antipsychotic chlorpromazine in a three-choice drug discrimination procedure in rats. Psychopharmacology (Berl) 178: $67-77$

Porter JH, Walentiny DM, Philibin SC, Vunck SA, Crabbe JC (2008) A comparison of the discriminative stimulus properties of the atypical antipsychotic drug clozapine in DBA/2 and C57BL/6 inbred mice. Behav Pharmacol 19:530-542

Prus AJ, Baker LE, Meltzer HY (2004) Discriminative stimulus properties of 1.25 and $5.0 \mathrm{mg} / \mathrm{kg}$ doses of clozapine in rats: examination of the role of dopamine, serotonin, and muscarinic receptor mechanisms. Pharmacol Biochem Behav 77:199-208

Prus AJ, Philibin SD, Pehrson AL, Porter JH (2005a) Generalization to atypical antipsychotic drugs depends on training dose in rats trained to discriminate $1.25 \mathrm{mg} / \mathrm{kg}$ clozapine versus $5.0 \mathrm{mg} / \mathrm{kg}$ clozapine versus vehicle in a three-choice drug discrimination task. Behav Pharmacol 16:511-520

Prus AJ, Philibin SD, Pehrson AL, Stephens CL, Cooper RN, Wise LE, Porter JH (2005b) Generalization testing with atypical and typical antipsychotic drugs in rats trained to discriminate $5.0 \mathrm{mg} / \mathrm{kg}$ clozapine from vehicle in a two-choice drug discrimination task. Drug Dev Res 64:55-65

Prus AJ, Philibin SD, Pehrson AL, Porter JH (2006) Discriminative stimulus properties of the atypical antipsychotic drug clozapine in rats trained to discriminate $1.25 \mathrm{mg} / \mathrm{kg}$ clozapine $v 55.0 \mathrm{mg} / \mathrm{kg}$ clozapine vs. vehicle. Behav Pharmacol 17:185-194

Prus AJ, Pehrson AL, Philibin SD, Wood JT, Vunck SA, Porter JH (2008) The role of M1 muscarinic cholinergic receptors in the discriminative stimulus properties of $\mathrm{N}$-desmethylclozapine and the atypical antipsychotic drug clozapine. Psychopharmacology (this issue)

Reuters (2008) ACADIA pharmaceuticals announces results from ACP-104 Phase IIb Schizophrenia Trial. Press Release, June 16, 2008 http://www.reuters.com/article/pressRelease/idUS100572+ 16-Jun-2008+BW20080616

Reynolds GP (1997) What is an atypical antipsychotic? J Psychopharmacol 11:195-199

Richelson E (1999) Receptor pharmacology of neuroleptics: relation to clinical effects. J Clin Psychiatry 60(Suppl 10):5-14

Roth BL, Ciaranello RD, Meltzer HY (1992) Binding of typical and atypical antipsychotic agents to transiently expressed $5-\mathrm{HT}_{1 \mathrm{C}}$ receptors. J Pharmacol Exp Ther 260:1361-1365

Roth BL, Craigo MC, Choudhary MS, Uluer A, Monsma FJ Jr, Shen Y, Meltzer HY, Sibley DR (1994) Binding of typical and atypical antipsychotics agents to 5-hydroxytryptamine-6 and 5-hydroxytryptamine-7 receptors. J Pharmacol Exp Ther 268:1403-1410

Schreiber R, Brocco M, Millan MJ (1994) Blockade of the discriminative stimulus effects of DOI by MDL 100,907 and the 'atypical' antipsychotics, clozapine and risperidone. Eur J Pharmacol 264:99-102

Schmidt WJ, Volz TL (1992) Clozapine-like discriminate stimulus effects of $N$-methyl-D-aspartate (NMDA). Journal of Psychopharmacology (Suppl.), Abstract: BAP and EBPS Joint Meeting, Cambridge

Schuster CR, Balster RL (1997) The discriminative stimulus properties of drugs. In: Thompson T, Dews PB (eds) Advances in behavioral pharmacology (Vol. 1). Academic, New York, pp 85-138

Schotte A, Janssen PFM, Gommeren W, Luyten WHML, Van Gompel P, Lesag AS, De Loore K, Leysen JE (1996) Risperidone compared with new and reference antipsychotic drugs: in vitro and in vivo receptor binding. Psychopharmacology 124:57-73 
Shapiro DA, Renock S, Arrington E, Chiodo LA, Liu LX, Sibley DR, Roth BL, Mailman R (2003) Aripiprazole, a novel atypical antipsychotic drug with a unique and robust pharmacology. Neuropsychopharmacology 28:1400-1411

Smith JA, Goudie AJ (2002) Discriminative stimulus properties in rats of the novel antipsychotic quetiapine. Exp Clin Psychopharmacol 10:376-384

Smith JA, Taylor A, Goudie AJ, Kilpatrick IC, Needham PL (1998) Discriminative stimulus properties of the antipsychotic zotepine in clozapine cued rats. J Psychopharmacol 12(Suppl):A57

Sorensen SM, Kehne JH, Fadayel GM, Humphreys TM, Ketteler HJ, Sullivan CK, Taylor VL, Schmidt CJ (1993) Characterization of the 5-HT2 receptor antagonist MDL 100907 as a putative atypical antipsychotic: behavioral, electrophysiological and neurochemical studies. J Pharmacol Exp Ther 266:684-691

Stewart J (1962) Differential responses based on the physiological consequences of pharmacological agents. Psychopharmacologia 3: $132-138$

Stolerman IP, Mariathasan EA, White J-AW (1994) Implications of mixture research for discrimination of single drugs. Behav Pharmacol 5(Suppl):18

Stolerman IP, White J-AW, Mariathasan EA (1996) Generalizations between mixtures of drugs under "AND" and "AND-OR" discrimination procedures in rats. In: Harris LS (ed) Problems of drug dependence 1995.NIDA Monograph 162, U.S. Government Printing Office, Washington, DC, p 214

Tang AH, Franklin SR, Himes CS, Smith MW, Tenbrink RE (1997) PNU-96415E, a potential antipsychotic agent with clozapine-like pharmacological properties. J Pharmacol Exp Ther 281:440-447

Varvel SA, Vann RE, Wise LE, Porter JH (1999) Discriminative stimulus control with olanzapine: generalization to the atypical antipsychotic sertindole. Society for Neuroscience Abstracts 25:1571

Villanueva HF, Arezo S, Rosecrans JA, Porter JH (1990) Discriminative stimulus properties of clozapine. Society for Neuroscience Abstracts 16:248
Villanueva HF, Arezo S, Rosecrans JA (1992) Nicotine does not interact with the discriminative stimulus effects of clozapine in rats. Drug Dev Res 26(2):195-202

Weiner DM, Meltzer HY, Veinbergs I, Donohue EM, Spalding TA, Smith TT, Mohell N, Harvey SC, Lameh J, Nash N, Vanover KE, Olsson R, Jayathilake K, Lee M, Levey AI, Hacksell U, Burstein ES, Davis RE, Brann MR (2004) The role of M1 muscarinic receptor agonism of $\mathrm{N}$-desmethylclozapine in the unique clinical effects of clozapine. Psychopharmacology (Berl) 177:207-216

Wiley JL, Porter JH (1992) Serotonergic drugs do not substitute for clozapine in clozapine-trained rats in a two-lever drug discrimination procedure. Pharmacol Biochem Behav 43:961-965

Wiley JL, Porter JH (1993) Effects of serotonergic drugs in rats trained to discriminate clozapine from haloperidol. Bull Psychonomic Society 31:94-96

Winter JC, Rabin RA (1989) Yohimbine and serotonergic agonists: stimulus properties and receptor binding. In: Lal H, Fielding S (eds) Drugs as interoceptive stimuli. Drug Dev Res 16:327333

Wood E, Pehrson AL, Wood JT, Prus AJ, Meltzer HY, Porter JH (2007) The discriminative stimulus properties of the atypical antipsychotic ziprasidone in rats. Poster Presented at the 12th Biennial European Behavioral Pharmacology Society meeting in Tubingen, Germany. Abstract Published in Behavioural Pharmacology 18(Suppl 1):S70

Woodward ND, Purdon SE, Meltzer HY, Zald DH (2005) A metaanalysis of neuropsychological change to clozapine, olanzapine, quetiapine, and risperidone in schizophrenia. Intern $\mathrm{J}$ Neuropsychopharmacol 8:1-16

Young CR, Longhurst JG, Bowers MB Jr, Mazure CM (1997) The expanding indications for clozapine. Exp Clin Psychopharm 5: 216-234

Zeng XP, Le F, Richelson E (1997) Muscarinic m4 receptor activation by some atypical antipsychotic drugs. Eur J Pharmacol 321(3): 349-54 